University of New Hampshire

University of New Hampshire Scholars' Repository

8-22-2012

\title{
Constraining recent lead pollution sources in the North Pacific using ice core stable lead isotopes
}

\author{
B H. Gross \\ University of Maine - Main \\ K Kreutz \\ University of Maine - Main \\ Erich Osterberg \\ Dartmouth College \\ J R. McConnell \\ Desert Research Institute \\ M J. Handley \\ University of Maine - Main
}

See next page for additional authors

Follow this and additional works at: https://scholars.unh.edu/earthsci_facpub

\section{Recommended Citation}

Gross, B. H., K. J. Kreutz, E. C. Osterberg, J. R. McConnell, M. Handley, C. P. Wake, and K. Yalcin (2012), Constraining recent lead pollution sources in the North Pacific using ice core stable lead isotopes, J. Geophys. Res., 117, D16307, doi:10.1029/2011JD017270.

This Article is brought to you for free and open access by the Earth Sciences at University of New Hampshire Scholars' Repository. It has been accepted for inclusion in Earth Sciences Scholarship by an authorized administrator of University of New Hampshire Scholars' Repository. For more information, please contact Scholarly.Communication@unh.edu. 


\section{Authors}

B H. Gross, K Kreutz, Erich Osterberg, J R. McConnell, M J. Handley, Cameron P. Wake, and Kaplan Yalcin 


\title{
Constraining recent lead pollution sources in the North Pacific using ice core stable lead isotopes
}

\author{
B. H. Gross, ${ }^{1}$ K. J. Kreutz, ${ }^{1}$ E. C. Osterberg, ${ }^{2}$ J. R. McConnell, ${ }^{3}$ M. Handley, ${ }^{1}$ C. P. Wake, ${ }^{4}$ \\ and K. Yalcin ${ }^{5}$
}

Received 2 December 2011; revised 6 July 2012; accepted 10 July 2012; published 22 August 2012.

[1] Trends and sources of lead $(\mathrm{Pb})$ aerosol pollution in the North Pacific rim of North America from 1850 to 2001 are investigated using a high-resolution (subannual to annual) ice core record recovered from Eclipse Icefield (3017 masl; St. Elias Mountains, Canada). Beginning in the early 1940s, increasing $\mathrm{Pb}$ concentration at Eclipse Icefield occurs coevally with anthropogenic $\mathrm{Pb}$ deposition in central Greenland, suggesting that North American $\mathrm{Pb}$ pollution may have been in part or wholly responsible in both regions. Isotopic ratios $\left({ }^{208} \mathrm{~Pb} /{ }^{207} \mathrm{~Pb}\right.$ and $\left.{ }^{206} \mathrm{~Pb} /{ }^{207} \mathrm{~Pb}\right)$ from 1970 to 2001 confirm that a portion of the $\mathrm{Pb}$ deposited at Eclipse Icefield is anthropogenic, and that it represents a variable mixture of East Asian (Chinese and Japanese) emissions transported eastward across the Pacific Ocean and a North American component resulting from transient meridional atmospheric flow. Based on comparison with source material $\mathrm{Pb}$ isotope ratios, Chinese and North American coal combustion have likely been the primary sources of Eclipse Icefield $\mathrm{Pb}$ over the 1970-2001 time period. The Eclipse Icefield Pb isotope composition also implies that the North Pacific mid-troposphere is not directly impacted by transpolar atmospheric flow from Europe. Annually averaged $\mathrm{Pb}$ concentrations in the Eclipse Icefield ice core record show no long-term trend during 1970-2001; however, increasing ${ }^{208} \mathrm{~Pb} /{ }^{207} \mathrm{~Pb}$ and decreasing ${ }^{206} \mathrm{~Pb} /{ }^{207} \mathrm{~Pb}$ ratios reflect the progressive East Asian industrialization and increase in Asian pollutant outflow. The post-1970 decrease in North American $\mathrm{Pb}$ emissions is likely necessary to explain the Eclipse Icefield $\mathrm{Pb}$ concentration time series. When compared with low (lichen) and high (Mt. Logan ice core) elevation $\mathrm{Pb}$ data, the Eclipse ice core record suggests a gradual increase in pollutant deposition and stronger trans-Pacific Asian contribution with rising elevation in the mountains of the North Pacific rim.

Citation: Gross, B. H., K. J. Kreutz, E. C. Osterberg, J. R. McConnell, M. Handley, C. P. Wake, and K. Yalcin (2012), Constraining recent lead pollution sources in the North Pacific using ice core stable lead isotopes, J. Geophys. Res., 117, D16307, doi:10.1029/2011JD017270.

\section{Introduction}

[2] Lead $(\mathrm{Pb})$ is a non-essential and potentially toxic metal whose principal atmospheric sources are crustal dust, volcanoes, mining, smelting, waste incineration, coal

\footnotetext{
${ }^{1}$ Climate Change Institute and Department of Earth Sciences, University of Maine, Orono, Maine, USA.

${ }^{2}$ Department of Earth Sciences, Dartmouth College, Hanover, New Hampshire, USA.

${ }^{3}$ Division of Hydrologic Sciences, Desert Research Institute, Reno, Nevada, USA.

${ }^{4}$ Complex Systems Research Center, University of New Hampshire, Durham, New Hampshire, USA.

${ }^{5}$ Department of Geosciences, Oregon State University, Corvallis, Oregon, USA.

Corresponding author: K. Kreutz, Climate Change Institute, University of Maine, 236 Sawyer Hall, Orono, ME 04469, USA.

(karl.kreutz@maine.edu)

(C)2012. American Geophysical Union. All Rights Reserved. 0148-0227/12/2011JD017270
}

combustion and combustion of leaded-gasoline [Nriagu, 1989; Pacyna and Pacyna, 2001]. Anthropogenic emissions are currently 1-2 orders of magnitude greater than those from natural (crustal and volcanic) sources [Komárek et al., 2008]. Most anthropogenic $\mathrm{Pb}$ is emitted in the form of very fine $(0.5-1 \mu \mathrm{m})$ particulates with an atmospheric residence time of $\sim 10$ days [Settle and Patterson, 1991], which can therefore be deposited thousands of kilometers from their source(s) of emission. Recent evidence also indicates that $\mathrm{Pb}$-containing particulates are among the most efficient ice-forming substances in the atmosphere, and may play a crucial role in radiative forcing [Cziczo et al., 2009]. Atmospheric archives from remote environments in the form of tree rings [e.g., Bellis et al., 2004], ombrotrophic bog cores [e.g., Shotyk et al., 1996; Kylander et al., 2010], epiphytic lichens [e.g., Simonetti et al., 2003] and ice cores [Rosman et al., 1993; Zheng et al., 2007; McConnell and Edwards, 2008] provide detailed histories of $\mathrm{Pb}$ concentrations in the atmosphere, and have demonstrated that humans have been polluting the atmosphere with $\mathrm{Pb}$ for over 2500 


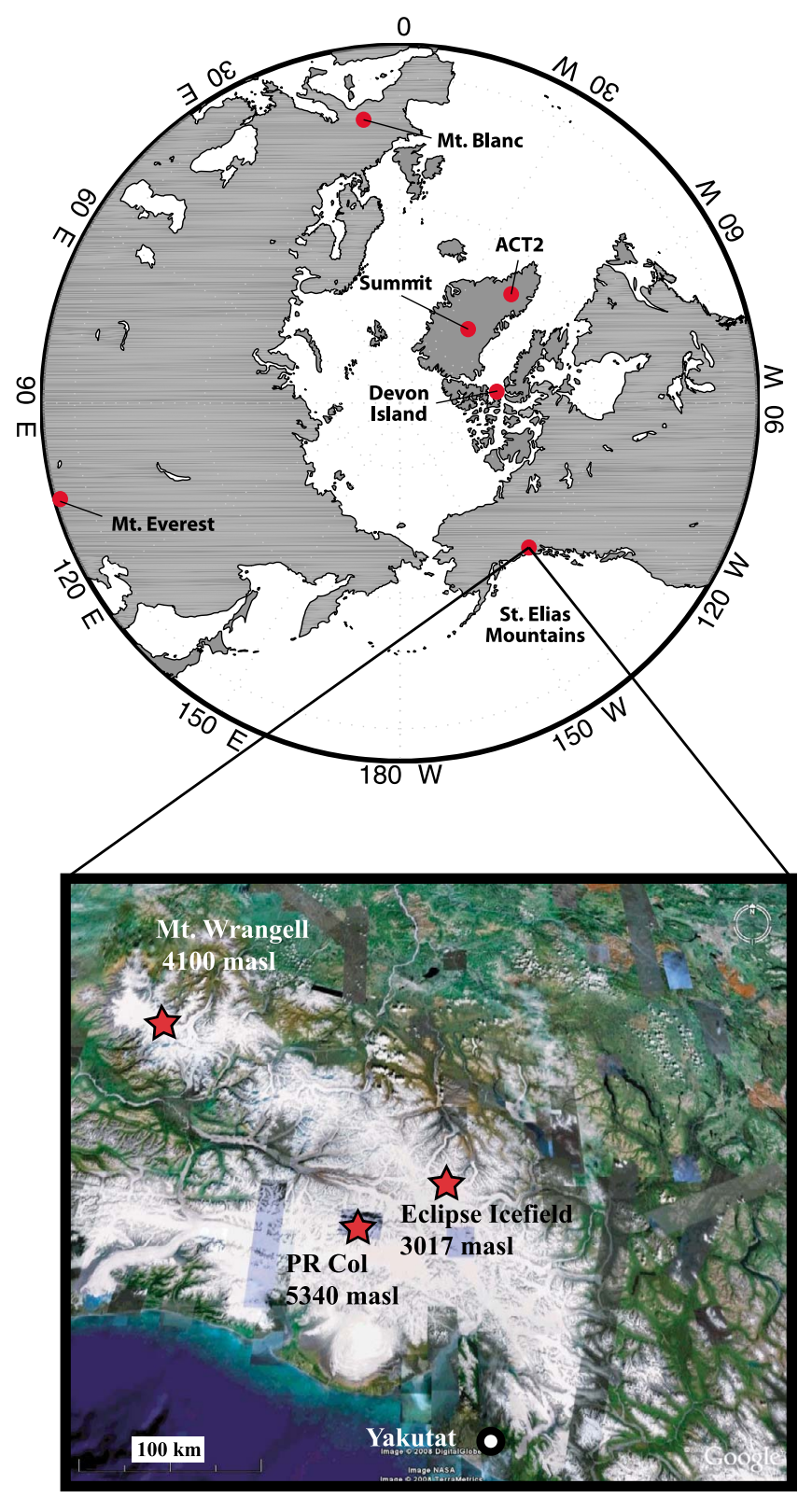

Figure 1. (top) Location map of ice core sites in the Northern Hemisphere with published $\mathrm{Pb}$ and $\mathrm{Pb}$ isotope records and (bottom) ice core sites in the St. Elias Mountains (Google Earth imagery (C) Google Inc. Used with permission).

years [Hong et al., 1994; Shotyk et al., 1996]. Ice and snow from Greenland, Antarctica, the European Alps, the Canadian Arctic, and recently the North Pacific have provided arguably the most well-preserved and highly resolved atmospheric $\mathrm{Pb}$ records [e.g., Boutron et al., 1991; Rosman et al., 2000; Schwikowski et al., 2004; Shotyk et al., 2005; Osterberg et al., 2008]. For example, the pioneering work of Murozumi et al. [1969] demonstrated an 500-fold increase in $\mathrm{Pb}$ concentrations in Greenland ice since pre-anthropogenic time, with an unprecedented increase from 1933-1965. Based in part on these findings, and as a result of automobile engineering improvements, North American and European governments adopted regulations limiting vehicular and industrial $\mathrm{Pb}$ emissions [Boutron et al., 1991]. These regulations have been effective in reducing atmospheric $\mathrm{Pb}$ concentrations in these regions since circa 1976, and this reduction is apparent in ice core records from Greenland, Europe, and the Canadian Arctic [Boutron et al., 1991; Schwikowski et al., 2004; McConnell and Edwards, 2008].

[3] Determining the isotopic ratios of $\mathrm{Pb}$ preserved in snow and ice can be used to distinguish natural $\mathrm{Pb}$ from anthropogenic $\mathrm{Pb}$ and also to identify specific sources of anthropogenic pollution [Bollhöfer and Rosman, 2001; Rosman et al., 1993, 1997, 2000; Shotyk et al., 2005; Komárek et al., 2008; Lee et al., 2011]. Four isotopes $\left({ }^{208} \mathrm{~Pb}\right.$, ${ }^{207} \mathrm{~Pb},{ }^{206} \mathrm{~Pb}$ and ${ }^{204} \mathrm{~Pb}$ ) comprise virtually all of $\mathrm{Pb}$ in the environment. ${ }^{208} \mathrm{~Pb},{ }^{207} \mathrm{~Pb}$ and ${ }^{206} \mathrm{~Pb}$ result from the decay series of ${ }^{232} \mathrm{Th},{ }^{235} \mathrm{U}$ and ${ }^{238} \mathrm{U}$, respectively, and ${ }^{204} \mathrm{~Pb}$ is a primordial isotope. The isotopic composition of $\mathrm{Pb}$, generally expressed in the form of a ratio (e.g., ${ }^{208} \mathrm{~Pb} /{ }^{207} \mathrm{~Pb}$, ${ }^{206} \mathrm{~Pb} /{ }^{207} \mathrm{~Pb}$ and ${ }^{208} \mathrm{~Pb} /{ }^{206} \mathrm{~Pb}$ ), depends on the age and geologic history of the $\mathrm{Pb}$ source as well as its initial concentrations of $\mathrm{U}, \mathrm{Th}$ and ${ }^{204} \mathrm{~Pb}$. The $\mathrm{Pb}$ isotope composition of ores and other resources (i.e., coal) are globally variable, but, for the most part, are regionally consistent [Komárek et al., 2008]. For example, $\mathrm{Pb}$ from the Mississippi Valley (USA) is more radiogenic (greater ${ }^{208} \mathrm{~Pb} /{ }^{207} \mathrm{~Pb}$ and ${ }^{206} \mathrm{~Pb} /{ }^{207} \mathrm{~Pb}$ ) than $\mathrm{Pb}$ from the Broken Hills region of Australia [Bollhöfer and Rosman, 2001]. Furthermore, isotopic ratios in $\mathrm{Pb}$ are not measurably fractionated by physical and chemical processes so that anthropogenic $\mathrm{Pb}$-aerosols transported thousands of kilometers retain the isotopic signature of their source material [Komárek et al., 2008]. By comparing the $\mathrm{Pb}$ isotope ratios in natural archives (e.g., ice cores) to those of regional emission source(s), atmospheric transport pathways and mixing processes can be constrained, making $\mathrm{Pb}$ isotopes a powerful geochemical tracer.

[4] Using ice core records from the North Atlantic region, European and North American $\mathrm{Pb}$ pollution trends and sources have been well constrained (see summary in Kylander et al. [2010]). Comparatively little is known about $\mathrm{Pb}$ pollution in the North Pacific [e.g., Osterberg et al., 2008]. In the past decade, considerable efforts have been made to quantify atmospheric pollution outflow from rapidly industrializing Asian countries and atmospheric monitoring stations in Western North America have observed the transPacific transport of dust and pollution from Asia [e.g., Jaffe et al., 1999; McKendry et al., 2001; Jacob et al., 2003; Liang et al., 2004; Holzer et al., 2005; Jacob et al., 2009; Singh et al., 2009]. An 8000 yearlong ice core record of atmospheric $\mathrm{Pb}$ deposition was developed by Osterberg et al. [2008] from a site (Prospector-Russell Col; PRC) at 5300 masl on the summit plateau of Mt. Logan in the St. Elias Mountains of the southwestern Yukon Territory (Figure 1). The PRC record registers an important rise in $\mathrm{Pb}$ deposition from 1981 to 1998 , that likely reflects enhanced trans-Pacific transport of $\mathrm{Pb}$ pollution accompanying the rapid industrialization of China and other East Asian nations [Osterberg et al., 2008]. However, other studies in the Canadian portion of the St. Elias Mountains have speculated that the influence of Asian air masses is minor at elevations below 3000 masl, thereby creating an elevational gradient of aerosol sources in the region [Yalcin and Wake, 2001; Wake et al., 2002; Zdanowicz et al., 2006]. Additional records from mid-tropospheric ice core sites are needed to test this hypothesis and better understand the history of $\mathrm{Pb}$ pollution 
in the North Pacific. Here we present a 151 yearlong (18502001) record of $\mathrm{Pb}$ concentrations and a 31 yearlong (1970 2001) record of $\mathrm{Pb}$ isotopes from Eclipse Icefield (EI) $\left(60.51^{\circ} \mathrm{N}, 139.47^{\circ} \mathrm{W}, 3017\right.$ masl), Yukon, Canada (Figure 1). Other ice core sites in the North Pacific [Osterberg et al., 2008] and Asia [Lee et al., 2011] are above 4000 masl and well into the free troposphere, but EI is within the planetary boundary layer (PBL) - free troposphere (FT) transition zone and therefore offers a unique perspective on $\mathrm{Pb}$ aerosols in the mid-troposphere. Using $\mathrm{Pb}$ concentration and isotopic data from the EI ice core, we provide direct geochemical evidence of the changing origin of $\mathrm{Pb}$ pollution to the North Pacific mid-troposphere through the 20th century.

\section{Materials and Methods}

[5] Several ice cores were recovered from EI $\left(60.51^{\circ} \mathrm{N}\right.$, $\left.139.47^{\circ} \mathrm{W}, 3017 \mathrm{masl}\right)$ in the St. Elias Mountains, Yukon, Canada during the summer of 2002 (Figure 1): a $345 \mathrm{~m}$ core (core 2), a $130 \mathrm{~m}$ core (core 3), and a $100 \mathrm{~m}$ core (core 4). All cores were drilled within $3 \mathrm{~m}$ horizontal distance of each other. Stable $\mathrm{O} / \mathrm{H}$ isotope ratios $\left(\delta^{18} \mathrm{O}, \delta \mathrm{D}\right)$ and major ion data from all three cores have been previously published [Yalcin et al., 2006a, 2006b, 2007]. The top $60 \mathrm{~m}$ of core 2 was drilled using the Geological Survey of Canada's ultraclean, titanium drill barrel [Zheng et al., 2006]. The drill barrel was lined with a pre-cleaned HDPE sleeve that was extruded with the core and sealed immediately to minimize potential contamination. Using a firn/ice core melting system and ultra-clean sample preparation and handling procedures [Osterberg et al., 2006], all of this portion of core 2 was continuously sampled at the University of Maine at high resolution $\left.(10-15 \mathrm{~cm} \mathrm{sample})^{-1}\right)$ to produce 492 discrete samples. For the determination of $\mathrm{Pb}$ isotope ratios, $4 \mathrm{~mm}$ aliquots from the uncontaminated, inner portion of the ice core were poured from the acid-cleaned primary collection containers to acid-cleaned polypropylene vials in a HEPA filtered laminar flow bench [Gross, 2008]. Ultra-pure Optima $^{\mathrm{TM}} \mathrm{HNO}_{3}$ was added to melted samples to make a $1 \%$ $\mathrm{HNO}_{3}$ solution. Samples remained acidified and liquid for 4-8 weeks prior to analysis. All $\mathrm{Pb}$ measurements were measured at low resolution on a Thermo-Finnigan Element 2 single-collector inductively coupled plasma-sector field mass spectrometer (ICP-MS) equipped with a guard electrode, a Cetac ASX 260 autosampler and a high-efficiency APEX Q sample introduction system with a $1.5 \mathrm{~mm}$ (inner diameter) quartz injector tube, a heated spray chamber and a Peltier cooled condenser. Self-aspirated PFA nebulizers were run at $200 \mu \mathrm{L} \mathrm{min}{ }^{-1} . \mathrm{Pb}$ isotope ratios $\left({ }^{206} \mathrm{~Pb},{ }^{207} \mathrm{~Pb}\right.$ and ${ }^{208} \mathrm{~Pb}$ ) were initially determined without a high-efficiency $\mathrm{x}$-cone in order to minimize damage to the slits of the mass spectrometer [Krachler et al., 2004]. Measurements with analytical errors greater than $0.4 \%$ were subsequently rerun with an $\mathrm{x}$-cone to improve precision. Detector dead time was calculated by standard protocol to be $15 \mathrm{~ns}$.

[6] National Institute of Standards and Technology (NIST) standard reference material (SRM) \#981 was dissolved in heated Optima ${ }^{\mathrm{TM}} \mathrm{HNO}_{3}$ and serially diluted to create a solution of $\sim 200 \mathrm{ng} \mathrm{Pb} \mathrm{L}{ }^{-1}$. This standard was analyzed every 1-4 samples to correct for mass bias. An average mass bias correction of the two bracketing NIST SRM \#981 measurements was applied to the measurements performed between the bracketing standards. The accuracy of $\mathrm{Pb}$ isotope measurements was assessed by comparing corrected ${ }^{208} \mathrm{~Pb} /{ }^{207} \mathrm{~Pb}$ and ${ }^{206} \mathrm{~Pb} /{ }^{207} \mathrm{~Pb}$ measurements of SRM 981 to the certified values. Corrected ${ }^{208} \mathrm{~Pb} /{ }^{207} \mathrm{~Pb}$ and ${ }^{206} \mathrm{~Pb} /{ }^{207} \mathrm{~Pb}$ ratios differed from certified values by an average $(\mathrm{n}=79)$ of $0.15 \%$ and $0.11 \%$ respectively. The analytical precision of individual samples (assessed by the standard deviation of $>300$ individual measurements per sample) averaged $0.24 \%$ and $0.25 \%$ for ${ }^{208} \mathrm{~Pb} /{ }^{207} \mathrm{~Pb}$ and ${ }^{206} \mathrm{~Pb} /{ }^{207} \mathrm{~Pb}$ respectively. Due to the precision necessary for source discrimination, any measurements with analytical error greater than $0.5 \%$ are discarded. The average procedural blank (10 samples of ultra-pure water (Milli-Q, 18 $\mathrm{M} \Omega$ ) subjected to the entire sampling procedure) is $1.6 \pm$ $0.03 \mathrm{ppt}$ [Osterberg et al., 2006], an order of magnitude lower than the lowest value, and is considered negligible.

[7] The annual chronology of the EI ice core was constructed from seasonal oscillations of stable water isotopes, major ion concentrations, and the identification of over 60 volcanic horizons, six of which have been confirmed via geochemical fingerprinting of tephra samples from the EI cores [Yalcin, 2005; Yalcin et al., 2003, 2006a, 2006b, 2007]. Additionally, ${ }^{137} \mathrm{Cs}$ marker horizons from the 1986 Chernobyl nuclear reactor accident and the 1963 atmospheric nuclear weapon test activity provides chronological tie-points. Error associated with the constructed chronology is estimated to be \pm 1 year based on repeat layer counts [Yalcin, 2005; Yalcin et al., 2003, 2006a, 2006b, 2007]. To construct seasonal divisions in the EI core record, $\delta \mathrm{D}$ minima are operationally defined as the middle of winter and $\delta \mathrm{D}$ maxima (within a given year) are operationally defined as the middle of summer. We then allocate samples between winter (summer) $\delta \mathrm{D}$ minima (maxima) into 4 bins, thereby creating 8 bins for an entire calendar year. We chose less than 12 bins to avoid implying monthly data resolution. The winter data set therefore represents the previous year's bin 8 and bin 1 , spring is bins $2-3$, summer bins $4-5$, and fall bins $6-7$. These seasonal divisions can only be approximate, because no ice core site receives constant snow accumulation throughout the year. However, meteorological data (snow surface height) from Divide Site ( $\sim 15 \mathrm{~km}$ south of EI, $\sim 2600$ masl) demonstrate that, in this portion of the St. Elias Mountains, snow accumulation occurs during all months [Gross, 2008] with a maximum in the fall. We emphasize that our goal is not to correlate specific meteorological conditions to individual samples, but rather to identify persistent seasonal climate/geochemical relationships at EI.

[8] To produce a longer, continuous 1850 to $2002 \mathrm{~Pb}$ concentration record from the Eclipse Icefield, contiguous (with respect to chronology), longitudinal samples with cross-sections of $3 \mathrm{~cm}^{2}$ were cut from remaining portions of cores 2, 3, and 4 and analyzed at the Desert Research Institute using a continuous flow analysis with trace elements (CFA-TE) system [McConnell et al., 2002b, 2007a, 2007b; McConnell and Edwards, 2008]. Chronologies developed using stable $\mathrm{O} / \mathrm{H}$ isotopes, major ions, and trace elements for each core were compared to ensure accurate matching of the DRI and UMaine measurements with depth, and the highresolution DRI measurements were combined to produce annually averaged $\mathrm{Pb}$ concentrations. Overlapping portions (1970-2001) of EI Pb annual concentration data produced at UMaine and $\mathrm{DRI} \mathrm{Pb}$ data have mean values of $66.3 \pm 19.3$ 


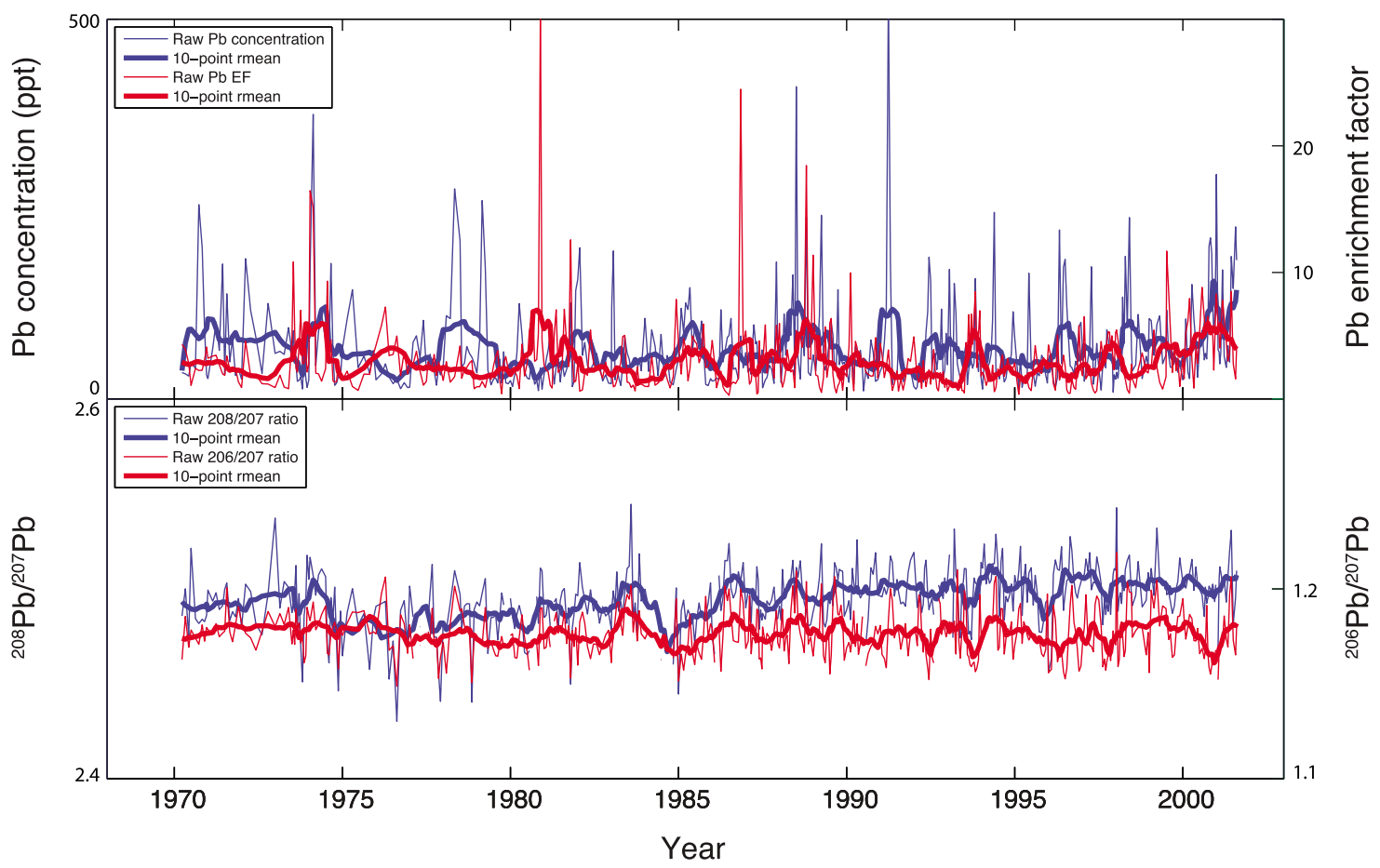

Figure 2. $\mathrm{Pb}$ concentration, $\mathrm{Pb}$ enrichment factor, and $\mathrm{Pb}$ isotope ratio $\left({ }^{208} \mathrm{~Pb} /{ }^{207} \mathrm{~Pb}\right.$ and $\left.{ }^{206} \mathrm{~Pb} /{ }^{207} \mathrm{~Pb}\right)$ data from the Eclipse Icefield ice core. Raw data (thin lines) represent the full 492-sample data set, and thick lines are 10-point running mean smoothed data.

and $44.7 \pm 14.2 \mathrm{ppt}$, respectively, which are statistically different based on a simple two sided t-test. We note, however, that the higher mean $\mathrm{Pb}$ value obtained at UMaine is consistent with recent work demonstrating that measured concentrations of trace elements leached from environmental samples and from rock standards are strongly dependent on the strength of acid used and on the length of acidification prior to analysis. Differences in the measured concentrations of trace elements between continuous injection ICP-MS and discretely analyzed ICP-MS systems are well-documented; for example, Knüsel et al. [2003] enumerate elements that show good and poor agreement between continuous-flow and conventional analyses. Rhodes et al. [2011] similarly found dramatic increases in trace elemental concentrations through time for four different rock standards. Importantly, different elements behaved quite differently through time, complicating the calculation and use of enrichment factors in ice core studies. They found that $\mathrm{Pb}$ increased on the order of $50 \%$ from $10 \mathrm{~min}$ to $12 \mathrm{~h}$ of leaching for a given standard (Nod-P-1), and that the concentration continued to increase up to 7 weeks (the length of the study). Finally, experimental data from UMaine (B. Koffman et al., manuscript in preparation, 2012) are consistent with existing evidence: for example, from 20 min to 28 days, Koffman et al. observe a $250 \%$ increase in measured $\mathrm{Pb}$ concentrations in Antarctic snow, acidified at $1 \%$ nitric acid. We therefore believe that the $\sim 30 \%$ high mean $\mathrm{Pb}$ value in UMaine samples is within the uncertainty introduced by different sample acidification schemes. The two $\mathrm{Pb}$ concentration time series (5-year average) are significantly correlated ( $r=0.55, p=0.001$; Figure 7) and when compared in time series the trends in the UMaine and $\mathrm{DRI} \mathrm{Pb}$ concentration data sets are roughly similar with decreasing concentrations through the 1970 s and slightly increasing concentrations in the 1990s. We are not aware of any similar research investigating the effects of acidification strength and time on $\mathrm{Pb}$ isotope ratios, and thus it is more difficult to assess the reliability of comparisons between various snow and ice core $\mathrm{Pb}$ isotope studies. We note that to date, all snow/ice core $\mathrm{Pb}$ isotope data have come from discrete sample processing, and determined either via thermal ionization mass spectrometry (TIMS) or ICP-MS techniques that utilize different processing schemes. Individual $\mathrm{Pb}$ isotopes may leach at constant rates, such that isotope ratios are preserved even at different overall $\mathrm{Pb}$ concentrations, thereby negating the importance of acidification technique on $\mathrm{Pb}$ isotope ratio data. In the absence of any compelling evidence regarding this idea, we proceed with the assumption that the new Eclipse $\mathrm{Pb}$ isotope data can be directly compared to other snow/ice core $\mathrm{Pb}$ isotope data.

\section{Results and Discussion}

\subsection{Pb Concentration and Enrichment Factor}

[9] Figure 2 shows the EI ice core subannual $\mathrm{Pb}$ concentration time series, which contains a high degree of intra and interannual variability over the 1970-2001 time period. A portion of the $\mathrm{Pb}$ deposition is likely from crustal dust aerosol, and indeed several studies have observed an increase in deposition/concentration of anthropogenic pollutants concurrent with certain dust deposition events [Han et al., 2004; Jaffe et al., 2003; Mori et al., 2003; Marx et al., 2005, 2008]. Crustal $\mathrm{Pb}$ enrichment factors $\left(\mathrm{EF}_{\mathrm{Pb}}\right)$ estimate the amount of non-crustal $\mathrm{Pb}$ in a sample by dividing the ratio of $\mathrm{Pb}$ to a crustal reference element in a sample by the ratio of the same elements in the upper 
continental crust $\left(\mathrm{UCC}\right.$ [Wedepohl, 1995]; $\mathrm{EF}_{\mathrm{Pb}}=$ average $\left([\mathrm{Pb}] /[\mathrm{r}]_{\text {sample }} \div[\mathrm{Pb}] /[\mathrm{r}]_{\mathrm{UCC}}\right)$. Following the method described in Osterberg et al. [2008], we use the average $\mathrm{EF}_{\mathrm{Pb}}$ calculated using seven crustal reference elements $(\mathrm{Sr}$, $\mathrm{Cs}, \mathrm{U}, \mathrm{Al}, \mathrm{Fe}, \mathrm{La}$, and $\mathrm{Ce}$ ) to reduce potential bias from any one crustal reference element. While the seven crustal reference element time series are highly correlated $(r>0.64 p<$ 0.0001), they are not identical nor are the calculated $\mathrm{EF}_{\mathrm{Pb}}$ values (average $\mathrm{EF}_{\mathrm{Pb}}$ for $\mathrm{Sr}=1.8, \mathrm{Cs}=1.7, \mathrm{U}=1.5, \mathrm{Al}=$ $4.6, \mathrm{Fe}=2.4, \mathrm{La}=4.6$, and $\mathrm{Ce}=4.7$ ) because of mineralogical and geochemical considerations, solubility and fractionation during transport, and measurement uncertainty. The average $\mathrm{EF}_{\mathrm{Pb}}$ at $\mathrm{EI}$ calculated from all seven reference elements for 1970-2001 is 3.0, which indicates that roughly a third of the $\mathrm{Pb}$ deposited at $\mathrm{EI}$ is anthropogenic, assuming approximately equal natural contributions from crustal and volcanic sources based on the reported average $\mathrm{EF}_{\mathrm{Pb}}$ value of 2.1 for pre-anthropogenic ice from Mt. Logan [Osterberg et al., 2008]. For comparison, over the same time period the $\mathrm{EF}_{\mathrm{Pb}}$ in the Mt. Logan ice core is $>30$ [Osterberg et al., 2008], suggesting a greater proportion of anthropogenic pollutant deposition at high elevations in the St. Elias range. The EI EF $\mathrm{Pb}$ time series (Figure 2) shows a similar degree of variability to the $\mathrm{Pb}$ concentration time series, but with different maxima as expected based on anthropogenic versus crustal inputs. We note that there is no obvious change in either $\mathrm{Pb}$ concentration or $\mathrm{Pb} \mathrm{EF}$ during or after the 1976/77 Pacific Decadal Oscillation (PDO) shift observed in the North Pacific Ocean [e.g., Mantua and Hare, 2002]. While the PDO mode shift had clear effects on North Pacific regional temperature and precipitation variability, it is less clear how the shift may have impacted trans-Pacific aerosol transport to Eclipse, particularly given the effect of aerosol emission strength and vertical aerosol distribution [Zhao et al., 2006]. A 40-year transport simulation study did not show any significant shift in dust transport from Asia during the mid-1970s [Zhao et al., 2006], however there is clear evidence for the impact of the PDO on trans-Pacific aerosol transport [e.g., Gong et al., 2006]. We speculate that the lack of an obvious correlation of the PDO and Eclipse Pb deposition may be related to the vertical nature of aerosol transport, and the influence of North American $\mathrm{Pb}$ at the Eclipse elevation.

[10] A seasonal maximum in dust aerosol deposition during spring in the St. Elias has been noted by several studies [Goto-Azuma et al., 2006; Osterberg et al., 2008; Gross, 2008]. The seasonal pattern of $\mathrm{Pb}$ concentration at Eclipse is less coherent than that of marine $\left(\mathrm{Na}^{+}\right)$and dust (Al) aerosol species [Yalcin, 2005; Gross, 2008], but nonetheless does show increases in $\mathrm{Pb}$ deposition during portions of the year (Figure 3) [Gross, 2008]. Concentrations between the 25th and 75th percentiles and the median are highest during spring and early summer and gradually decline to their lowest during autumn and winter. Concentrations above the 75th percentile are highest during spring and early summer, but are also slightly elevated during winter. The elevated concentrations during late spring and early summer are concomitant with the peak in ice core dust concentration [Gross, 2008] and maximum springtime Asian dust outflow [e.g., Uno et al., 2009], suggesting that dust is acting as a vector for $\mathrm{Pb}$ and/or that $\mathrm{Pb}$ and dust are being transported independently by the same synoptic systems. We are unable to resolve the relative importance of these processes, but assume that they are both significant based on previous dust$\mathrm{Pb}$ interaction studies [Fukuda and Tsunogai, 1975; Marx et al., 2008], satellite imagery depicting dust and pollution in the same frontal system, and observations from the National Oceanic and Atmospheric Administration's (NOAA) Mauna Loa observatory (R. Schnell, personal communication, 2009). The slightly elevated levels of $\mathrm{Pb}$ concentration during winter could be a result of increased transport efficiency (e.g., a deepened Aleutian Low and increased trans- Pacific outflow of pollutants and/or dust in the lower troposphere; Liang et al., 2004, 2005; Osterberg et al., 2008]. $\mathrm{EF}_{\mathrm{Pb}}$ values show no distinct seasonality, but values are somewhat lower in late winter and spring (Figure 3). This observation appears consistent with the general picture of anthropogenic emissions from coal burning for electrical generation, waste-incineration, smelting and mining that have only minor seasonal variation [Van de Velde et al., 1998], and increased dust transport in spring.

\subsection{Pb Isotopes}

[11] Figure 4a shows the $\mathrm{Pb}$ isotope data set from the several northern hemisphere ice cores (including EI) compared with regional $\mathrm{Pb}$ isotope fields constructed from in situ measurements of atmospheric aerosol $\mathrm{Pb}$ in urban centers around the world [Bollhöfer and Rosman, 2001]. The aerosol fields are derived from spatially and temporally limited measurements (particularly for China and Russia) and thus may not capture the full range of $\mathrm{Pb}$ isotope ratios in aerosols from all regions. Nonetheless, they provide a baseline for comparison and interpretation of the ice core $\mathrm{Pb}$ isotope data. The $\mathrm{Pb}$ isotope ratios from $\mathrm{EI}$ are less radiogenic than those of upper continental crust (UCC; ${ }^{206} \mathrm{~Pb} /{ }^{207} \mathrm{~Pb}=1.21$, and ${ }^{208} \mathrm{~Pb} /{ }^{207} \mathrm{~Pb}=2.50$, using river sediments from major river basins [Millot et al., 2004] (Figure 4b), confirming the influence of anthropogenic $\mathrm{Pb}$. In a three-isotope plot, a binary mixture would plot as a linear array between the two end-member ratios. The EI data set does not form a linear array, suggesting that more than two sources contribute $\mathrm{Pb}$ to EI. In general, EI samples fall within and between the fields defining North American (primarily U.S.), Asian (Japanese and Chinese) and Russia/Eastern Europe aerosols (Figure $4 \mathrm{a}$ ). Figure $4 \mathrm{~b}$ compares the $\mathrm{EI} \mathrm{Pb}$ isotope data set to various source region fuel data (i.e., $\mathrm{Pb}$ isotope data from coal and leaded gasoline). As a whole, $\mathrm{Pb}$ isotope ratios from EI show very little evidence of $\mathrm{Pb}$ from Russian or Chinese leaded gasoline, which generally has a very low $\mathrm{Pb}$ isotope ratios (typically $<2.415$ and $<1.125$ for ${ }^{208} \mathrm{~Pb} /{ }^{207} \mathrm{~Pb}$ and ${ }^{206} \mathrm{~Pb} /{ }^{20} \mathrm{~Pb}$, respectively; Bollhöfer and Rosman, 2001]. Although leaded gasoline was phased out in North America and Europe beginning the 1970s, some influence from North American gasoline may be discernable in the $\mathrm{EI} \mathrm{Pb}$ isotope record for the 1970s and 1980s (Figure 4b). As with Pb EF values, there is no obvious seasonality in the $\mathrm{EI} \mathrm{Pb}$ isotope ratios (Figure 5).

[12] The published Chinese $\mathrm{Pb}$ aerosol isotope signature [Bollhöfer and Rosman, 2001] and high elevation ice core $\mathrm{Pb}$ isotope data from Mt. Everest [Lee et al., 2011] (Figure 4a) form an end-member that cannot be obtained by a combination of other potential $\mathrm{Pb}$-aerosol sources. Thus, $\mathrm{Pb}$ isotope ratios at EI provide geochemical evidence of transPacific transport of Asian pollutants to lower elevations 


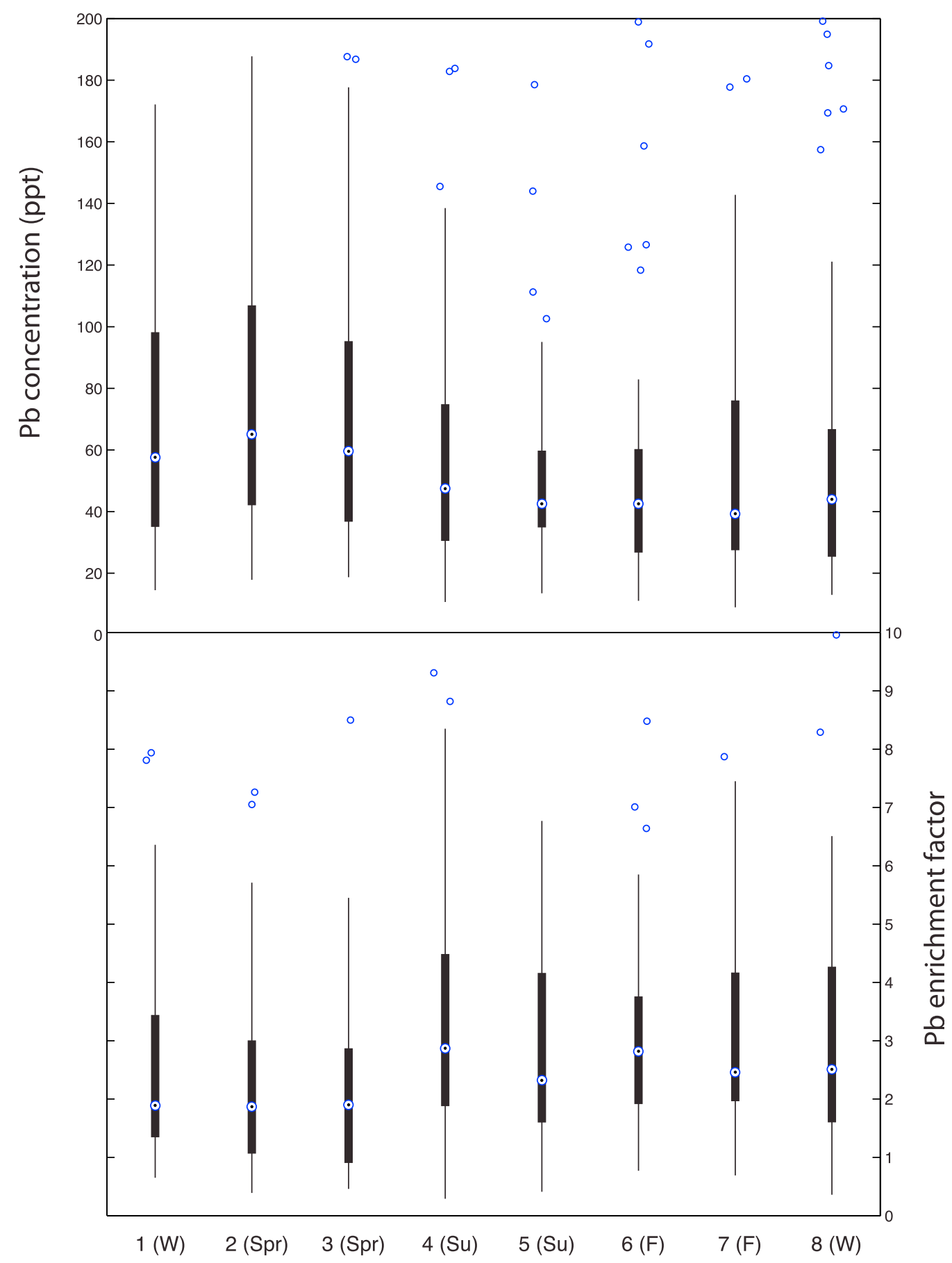

\section{Fractional Season}

Figure 3. $\mathrm{Pb}$ concentration and $\mathrm{Pb}$ enrichment factor data from the Eclipse Icefield ice core, grouped as described in section 2 according to fractional season (2-3, spring; 4-5; summer; 6-7 fall; 8 and 1, winter). Circles within the blue boxes are median values for all data in that bin, the edges of the boxes are the 25th and 75 th percentiles, and the whiskers extend to the most extreme data points not considered outliers (circles).

( 3000 masl) in the St. Elias Mountains. Several airborne sampling campaigns have documented pollutant outflow from Asia, and in particular have noted the layered structure of atmospheric chemistry over the North Pacific [Jacob et al. 2003; Singh et al., 2009]. The EI samples within the Chinese
$\mathrm{Pb}$ isotope field are similar to aerosol values from Mukai et al. [1993] and are similar to $\mathrm{Pb}$ isotope ratios in coal from Northern China (Figure 4b), which is consistent with coal being the dominant source of $\mathrm{Pb}$ aerosols in parts of China despite the fact that leaded gasoline was not banned in 


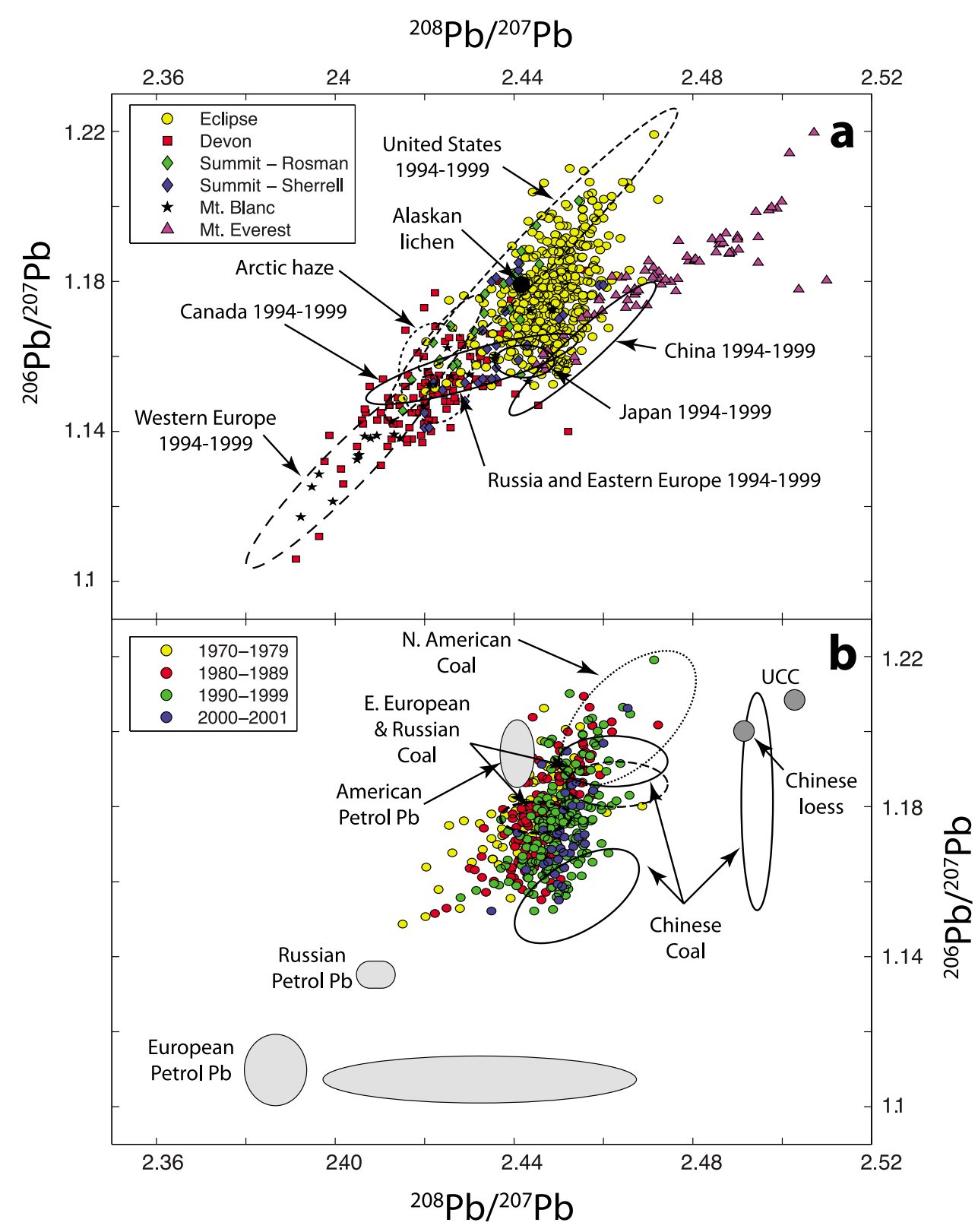

Figure 4. (a) $\mathrm{Pb}$ isotope composition of all samples from the Eclipse Icefield ice core compared to other recent (post-1970) Northern Hemisphere snow and ice core data (Devon Island ice core [Shotyk et al., 2005], Summit Greenland [Rosman et al., 1993], Mt. Blanc [Rosman et al., 2000], and Mt. Everest [Lee et al., 2011]), and nearby Alaska lichen [Simonetti et al., 2003]. Ellipses are fields of regionally characteristic $\mathrm{Pb}$ isotope ratios, determined from atmospheric aerosols [Bollhöfer and Rosman, 2001; Sturges et al., 1993]. (b) Pb isotope ratios of decadally binned samples from Eclipse Icefield ice core compared to $\mathrm{Pb}$ isotope ratios from Chinese leaded petrol [Chen et al., 2005], Chinese coal [Mukai et al., 1993; Komárek et al., 2008], Russian leaded petrol [Kober et al., 1999], Eastern European coal and Russian coal [Kober et al., 1999], North American coal [Chow and Earl, 1972], American leaded petrol [Sherrell et al., 1992; Teutsch et al., 2001], upper continental crust (UCC) [Millot et al., 2004], and Chinese loess [Jones et al., 2000].

China until 1997 [Chen et al., 2005]. Furthermore, the presence of Chinese $\mathrm{Pb}$ at $\mathrm{EI}$ is consistent with several studies that have observed the transport of Asian pollution to the Western U.S. by midlatitude westerlies [e.g., Jaffe et al., 1999]. Japanese $\mathrm{Pb}$ aerosols are isotopically indistinguishable from a combination of Eurasian and Chinese sources, and the meteorological conditions that transport Chinese $\mathrm{Pb}$ to EI would likely also transport $\mathrm{Pb}$ from Japan. Likewise, easterly transport from northern Asia may incorporate aerosol from Russia, resulting in the partial overlap of the EI and Russia/E. Europe Pb isotope fields. However, since 1991 total emissions of most pollutants from northern Asia (Russia) have been comparably small [Shindell et al., 2008]. While we cannot rule out a possible contribution from 


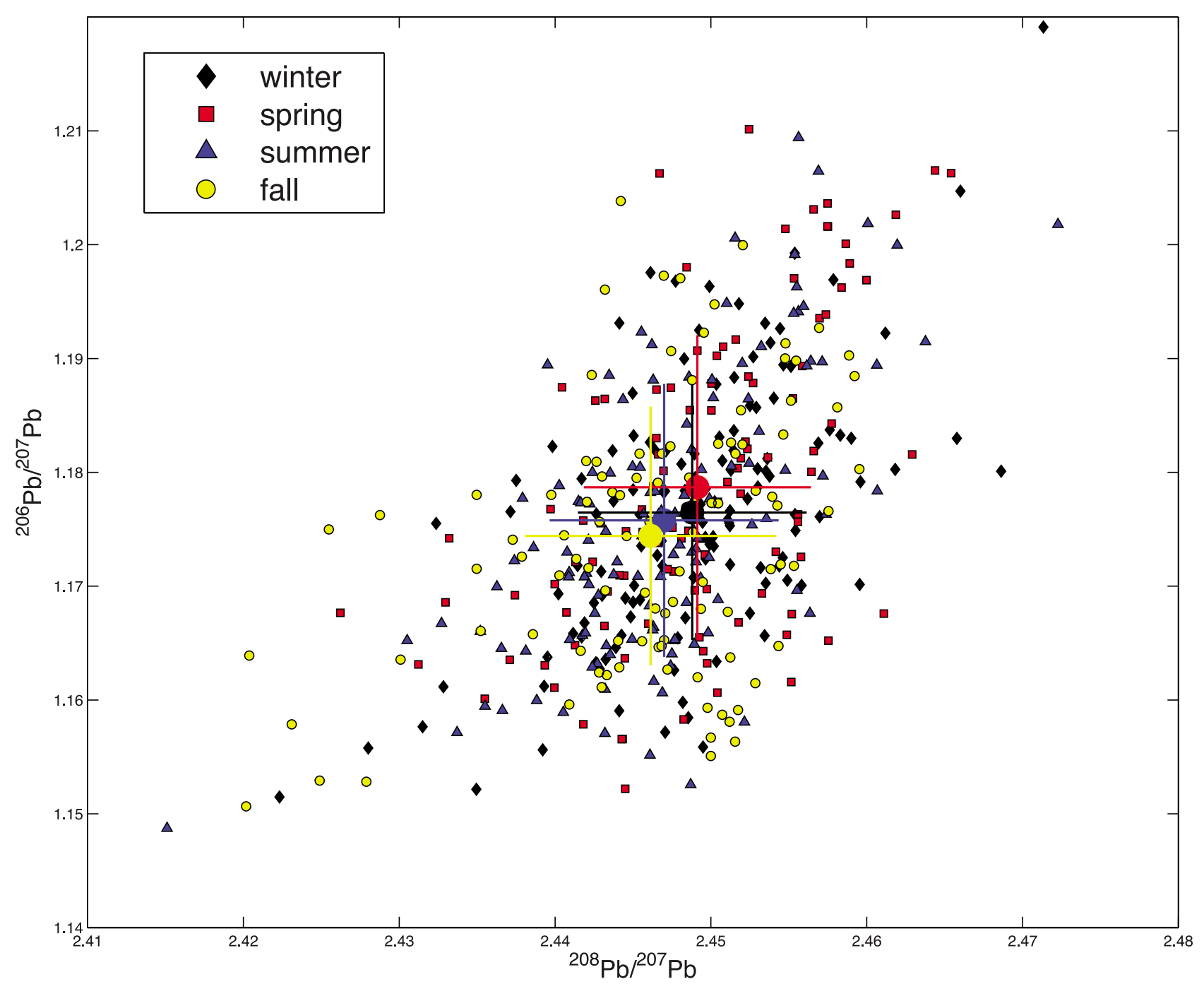

Figure 5. $\mathrm{Pb}$ isotope data from the Eclipse Icefield ice core plotted by season of deposition. Grouping into seasonal bins is described in section 2. Large circles represent mean values for each season, and error bars represent one standard deviation.

northern Asia based on available data, we infer that the majority of Asian $\mathrm{Pb}$ is derived from East Asia.

[13] The EI samples that plot within the North American (U.S.) $\mathrm{Pb}$ isotope field have similar $\mathrm{Pb}$ isotope ratios to North American $\mathrm{Pb}$ detected in Summit, Greenland [Rosman et al., 1993; Sherrell et al., 2000], Lake Erie [Graney et al., 1995] and the Sargasso Sea [Hamelin et al., 1997]. Prevailing midlatitude westerlies (Figure 6) suggest that North American air masses may not strongly and consistently contribute to atmospheric pollutant deposition in the North Pacific. During all seasons the atmosphere of the St. Elias Mountains is characterized by predominantly southerly flow from the Gulf of Alaska, which in turn, receives westerly flow from the North Pacific Ocean (Figure 6). However, these time-averaged views of atmospheric flow may obscure transient meridional patterns along the North American west coast that could affect the St. Elias Mountains. Modeling and backtrajectory studies during the 2008 ARCTAS mission indicate that, particularly during summer, airflow from the contiguous U.S. into the Arctic via the Northeast Pacific occurs on synoptic timescales and is responsible for significant pollutant transport [Fuelberg et al.,
2010]. Blocking of flow by high elevation Western North American topography may be responsible for flow from the Southwestern U.S., and results in Alaska being one of the primary entrance points to the Arctic for air departing near the surface [Fuelberg et al., 2010]. We therefore expect that the overlap of EI and North American (U.S.) Pb isotope fields, as well as the mixed EI composition between North American (U.S.) and East Asian fields results from this Southwestern U.S. pollutant contribution.

[14] Comparing $\mathrm{Pb}$ isotopic data from EI to those from Devon Island and Mt. Blanc (Figure 1 for location) is particularly useful (Figure 4a) for evaluating the role of Western European pollution in the Northeast Pacific. Using $\mathrm{Pb}$ isotopes and the seasonality of $\mathrm{Pb}$ deposition, Shotyk et al. [2005] concluded that $\mathrm{Pb}$ in recent snow (1994-2004) on Devon Island is derived from pollutant laden surface and upper air from Eurasia that dominates the winter atmosphere of the Arctic, known as Arctic Haze [Shaw, 1982, 1995; Quinn et al., 2007]. Similarly, on the basis of the seasonality of deposition, regional emissions trends, and correlations with ice core sulfate time series, Yalcin and Wake [2001] 

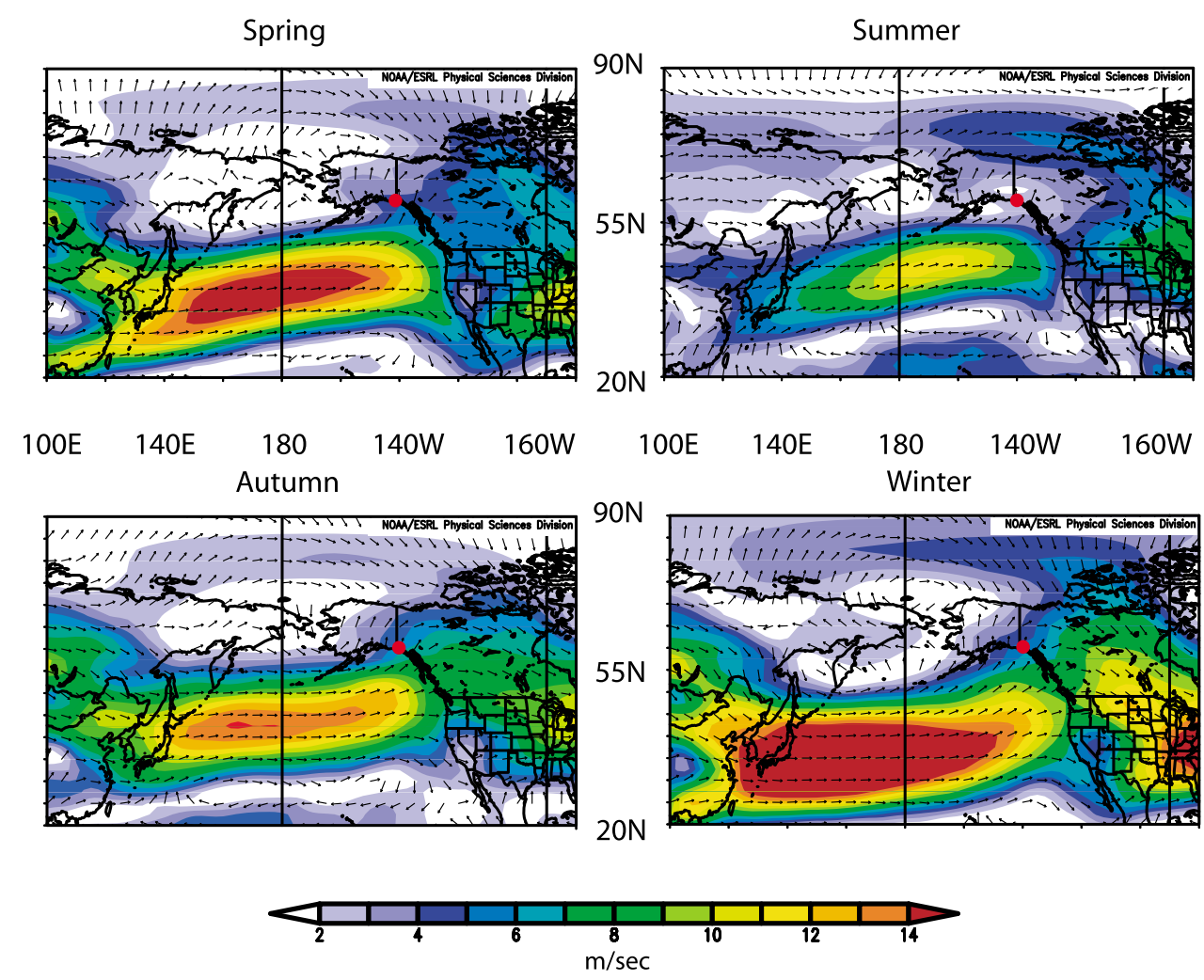

Figure 6. Seasonal average wind vectors $(\mathrm{m} / \mathrm{sec})$ at $700 \mathrm{mb}$ from 1971-2001 from NCEP/NCAR reanalysis [Kalnay et al., 1996]. Spring $=$ JFM, Summer $=$ JJA, Autumn $=$ SON, Winter $=$ DJF. The location of Eclipse Icefield is noted with a red circle.

suggested that sulfate at EI is predominantly comprised of Arctic Haze. However, $\mathrm{Pb}$ isotope ratios from EI are significantly more radiogenic (higher ${ }^{208} \mathrm{~Pb} /{ }^{207} \mathrm{~Pb}$ and ${ }^{206} \mathrm{~Pb} /{ }^{207} \mathrm{~Pb}$ ) than those measured in polluted air in Barrow, Alaska [Sturges et al., 1993] and on Devon Island and Mt. Blanc [Shotyk et al., 2005; Rosman et al., 2000]. Arctic Haze was originally understood to contain a significant amount of pollution from Western Europe and northern Eurasia [e.g., Sturges et al., 1993; Quinn et al., 2007], particularly for aerosol species, which in the case of $\mathrm{Pb}$ are less radiogenic than East Asian or North American emissions (Figure 4a). In this sense, the $\mathrm{EI} \mathrm{Pb}$ isotope data show a distinct difference from those sites in the North Atlantic sector of the Arctic (Devon Ice Cap) and the European Alps (Mt. Blanc), namely a lesser influence of Western Europe emissions. This finding is consistent with the relative influence of trans-Pacific westerly flow (Figure 6) at EI, and circumpolar (northerly/ northwesterly) flow at sites in Northern Alaska and the Canadian Arctic. Recent observational [Stohl, 2006] and modeling [Shindell et al., 2008] studies have demonstrated that pollutant transport into the Arctic occurs along numerous pathways which have both spatial and vertical heterogeneity, and which can be unique for various pollutant types (e.g., gases, sulfate, metal, and black carbon aerosols). Therefore, the Arctic Haze signal at a particular site may contain a distinct mixture of pollutant type and source contribution (generalized as North America, East Asia, South Asia, and Europe by Shindell et al. [2008]). Based on the EI Pb isotope data, we suggest that Arctic Haze at EI has a composition and mixture of sources unique among Northern Hemisphere ice core sites thus far studied.

[15] To investigate temporal variability in EI data, the $\mathrm{Pb}$ isotope values are grouped decadally (Figure 4b). The frequency of samples with $\mathrm{Pb}$ isotope ratios characteristic of Chinese aerosols increases from the 1970s to 1990s, which can also be seen in the progressively more radiogenic character of the ${ }^{208} \mathrm{~Pb} /{ }^{207} \mathrm{~Pb}$ ratio with time (Figure 2). During the 1980s and 1990s, Pb emissions from China increased in response to higher energy demands resulting from rapid industrialization, while $\mathrm{Pb}$ emissions from North America, Europe and Russia decreased with increased regulation (North America, Europe) and decreasing economic output (Russia; Pacyna and Pacyna, 2001]. Thus, the shift in $\mathrm{Pb}$ isotopic composition observed at EI from 1970 to 2000 is likely the result of a progressively larger contribution from Chinese aerosols to the $\mathrm{Pb}$ flux at EI.

\subsection{Pb Concentration Time Series}

[16] The annually resolved $\mathrm{EI} \mathrm{Pb}$ concentration data set from 1850 to 2001 provides a longer context within which to evaluate changes in North Pacific pollutant transport relative to the North Atlantic (Figure 7). Changes in Greenland $\mathrm{Pb}$ concentration over the past 150 years have been well documented, and include a pronounced increase beginning in the 1940s [e.g., Mc Connell and Edwards, 2008]. Comparison of the Southern Greenland ACT2 and EI Pb data sets reveals a nearly identical rise in mid-tropospheric North Pacific $\mathrm{Pb}$ deposition, which is consistent with $\mathrm{Pb}$ isotope results implying North American influence in the Gulf of Alaska 


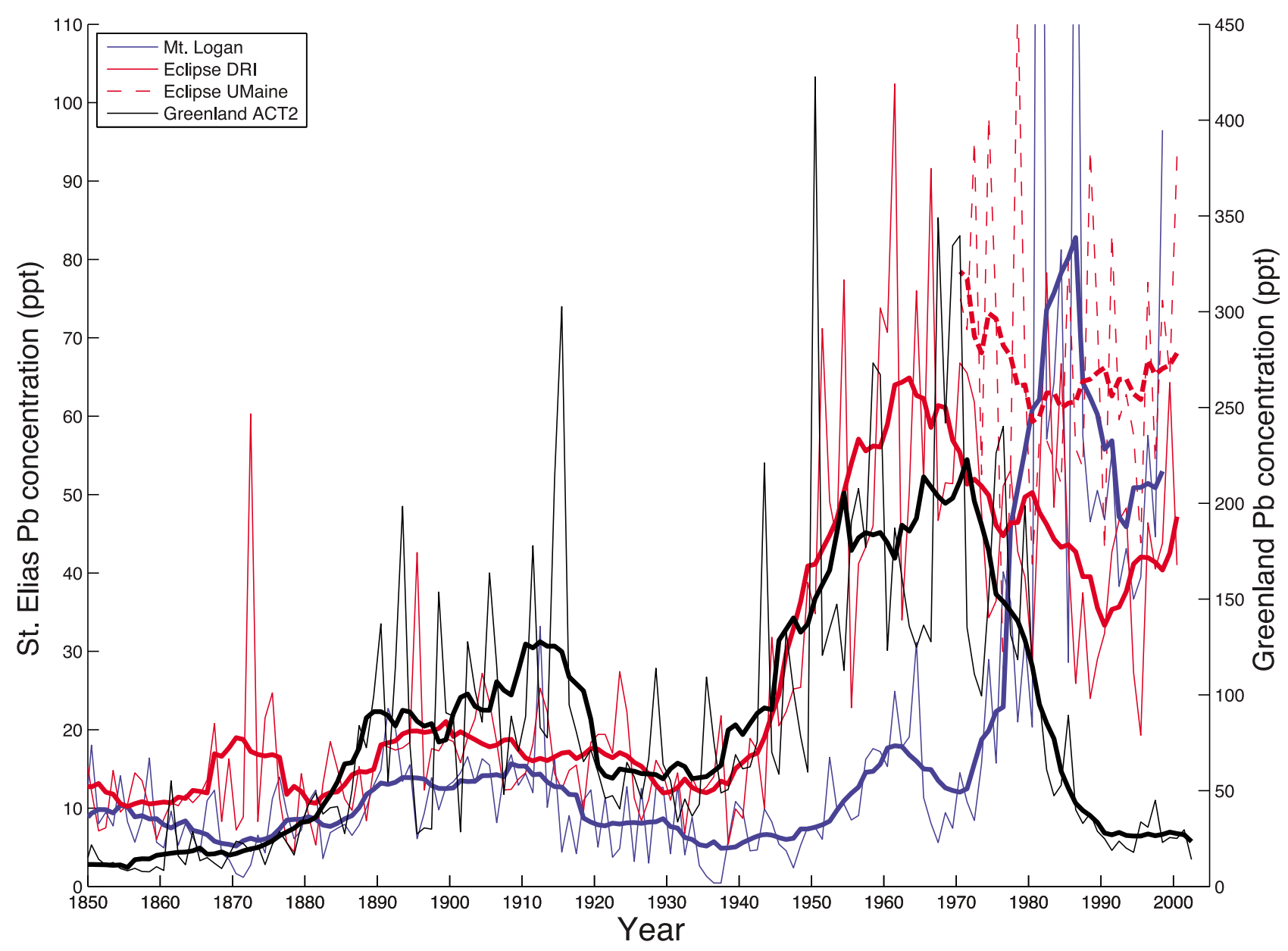

Figure 7. Comparison of annual and 5-year smoothed, 1850 to $2002 \mathrm{~Pb}$ concentration data from EI with the Mt. Logan (PR Col) summit [Osterberg et al., 2008] and the Greenland ACT2 ice core records [McConnell and Edwards, 2008].

region. The decline in North Atlantic $\mathrm{Pb}$ concentration, typically attributed to phase-out of leaded gasoline in the early 1970s, begins concomitantly in the North Pacific. However, beginning around 1970, the trends in the two regions clearly diverge, with North Atlantic concentrations returning to pre-industrial background levels, and EI concentrations remaining elevated above background.

[17] Previous work with the Mt. Logan summit ice core has shown an obvious disparity between $\mathrm{Pb}$ concentration time series from high elevation (>5000 masl) North Pacific sites and the North Atlantic (Figure 7). Osterberg et al. [2008] attributed the sharp rise in $\mathrm{Pb}$ concentration starting in the in the late 1970s as reflecting increased East Asian economic activity and pollutant emission. The rise in presumably Asian $\mathrm{Pb}$ in the Mt. Logan record begins essentially at the time when the EI and Greenland trends diverge (Figure 7). The increase in East Asian $\mathrm{Pb}$ emissions is not obvious in the $\mathrm{EI} \mathrm{Pb}$ concentration time series from 1970 to 2001 (Figure 8; the period with $\mathrm{Pb}$ isotope data). Annually averaged $\mathrm{EI} \mathrm{Pb}$ concentrations range from $25.6 \mathrm{ppt}$ in 1976 to $96.7 \mathrm{ppt}$ in 1978 (mean $67.6 \pm 20.6 \mathrm{ppt}(1 \sigma)$ ), with no discernable long-term trend in annual flux or interannual variability over the 1970-2001 period. For comparison we also plot (Figure 8) annual $\mathrm{Pb}$ flux in the Eclipse record, calculated using annual concentration and accumulation rate data [e.g., Alley et al., 1995]. While there is an increasing trend in the $\mathrm{Pb}$ flux data, the trend is clearly being driven by an increase in accumulation rate during 1970-2001 (Figure 8). Because it is generally accepted that ice core concentration data likely provide the best representation of atmospheric concentration at sites (such as EI, with an annual accumulation rate of $\sim 1.5$ mwe $\mathrm{yr}^{-1}$ ) dominated by wet deposition [Alley et al., 1995], we choose to use the EI Pb concentration time series for comparison with other ice core data. The lack of trend in $\mathrm{EI} \mathrm{Pb}$ concentration is in contrast to the records from Greenland (Figure 7) and Devon Island [Shotyk et al., 2005] not shown]. The Greenland and Devon Island $\mathrm{Pb}$ concentration records exhibit a dramatic decline beginning circa 1970 in response to North American and European $\mathrm{Pb}$ emissions regulations [McConnell et al., 2002a; Shotyk et al., 2005; McConnell and Edwards, 2008], while PR Col Pb concentrations drastically increase during the 1980s in response to Chinese industrialization [Osterberg et al., 2008]. This distinction is further evidence that anthropogenic $\mathrm{Pb}$ at $\mathrm{EI}$ in the latter part of the 20th century is neither predominantly from North American, European, and Eurasian sources (as at Devon Island and ACT2) nor from predominantly Asian sources (as at PR Col), but likely 


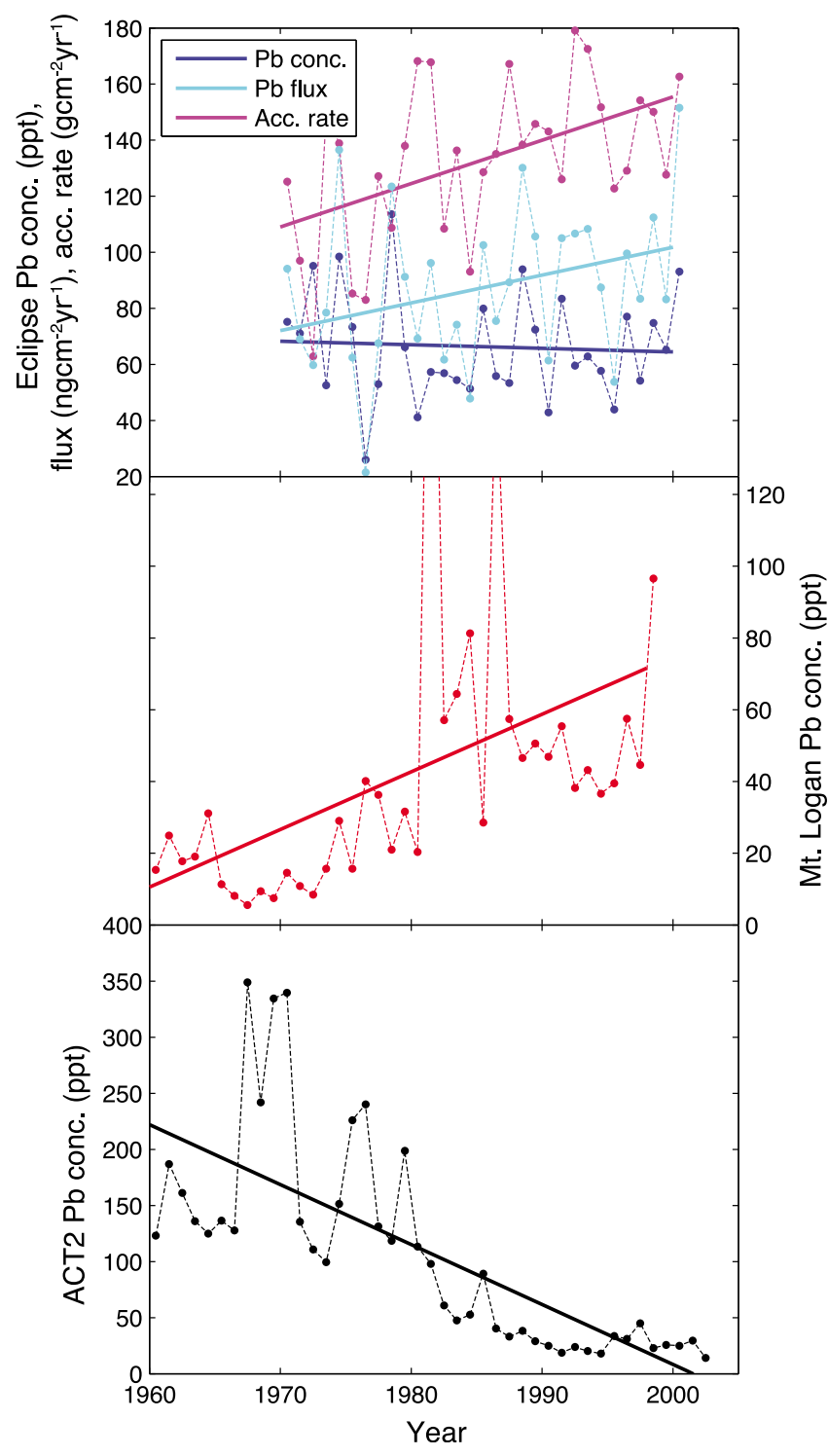

Figure 8. Comparison of $\mathrm{Pb}$ concentration records. (top) Eclipse Icefield ice core $\mathrm{Pb}$ concentration (1-year averages in $\mathrm{ppt}$; linear regression slope $=-0.12 \mathrm{ppt} / \mathrm{yr}, p=0.75)$, including annual accumulation rate (in $\mathrm{gcm}^{-2} \mathrm{yr}^{-1}$; linear regression slope $\left.=1.5 \mathrm{gcm}^{-2} \mathrm{yr}^{-1} / \mathrm{yr}, p=0.005\right)$ and annual $\mathrm{Pb}$ flux (in $\mathrm{ngcm}^{-2} \mathrm{yr}^{-1}$; linear regression slope $=1.0 \mathrm{ngcm}^{-2} \mathrm{yr}^{-1}$, $p=0.08$ ). (middle) Prospector - Russell (PR) Col ice core on the summit plateau of Mt. Logan, Yukon, Canada (1-year average [Osterberg et al., 2008]; linear regression slope = $1.6 \mathrm{ppt} / \mathrm{yr}, p=0.008$ ). (bottom) Greenland ACT2 site (1-year average [McConnell and Edwards, 2008]; linear regression slope $=-5.3 \mathrm{ppt} / \mathrm{yr}, p=0.00001)$. Trend lines in all plots are one-dimensional least squares linear regression.

represents a mixture of decreasing North American and increasing East Asian sources with the importance of East Asian sources increasing with time.

[18] We return now to the hypothesis that there is a distinct vertical separation of pollutant aerosol deposition in the St. Elias, such that sites above 5000 masl receive predominantly Chinese pollution [Osterberg et al., 2008], and sites below receive predominately Eurasian pollution [Yalcin and
Wake, 2001; Wake et al., 2002]. Based on the $\mathrm{Pb}$ isotope and concentration data presented here, we conclude that the Asian influence is clear at both sites, however additional pollutant contributions from North America affect lower elevations. A similar conclusion was reached by other sampling campaigns, including those looking at vertical changes in snow chemistry in the St. Elias Mountains [Zdanowicz et al., 2006], low elevation aerosol and lichen sampling in Alaska [Cahill, 2003; Simonetti et al., 2003] (Figure 4a), and airborne dust and pollutant aerosol sampling over the North Pacific [Bahreini et al., 2003; Oshima et al., 2004; Huang et al., 2008]. Each of these studies has demonstrated the influence of Chinese aerosols at all levels of the North Pacific atmosphere, albeit with significant complexity with respect to layered aerosol distribution. Low elevation sites (e.g., Adak Island, SE Alaska) demonstrate the additional influence of North American, Northern Europe and Russian aerosols [Cahill, 2003; Simonetti et al., 2003]. Given the overall dominance of Asian pollution in the North Pacific, the more perplexing issue is why there is not an increasing trend in $\mathrm{Pb}$ concentration (flux) in the EI record. The PR Col ice core clearly shows a large increase in $\mathrm{Pb}$ deposition over the past several decades that is not matched in the EI record, and $\mathrm{EF}_{\mathrm{Pb}}$ values at PR Col an order of magnitude higher than at EI. Answering this question likely requires, at a minimum, $\mathrm{a} \mathrm{Pb}$ isotope time series from the PR Col ice core. However, insight may come from the conceptual model of Holdsworth [2008], whereby the three dimensional nature of cyclones impacting the St. Elias Mountains lead to a complex vertical profile of local moisture (and presumably aerosol) flux. Indeed, during a single large Asian outflow event in 2001, Zdanowicz et al. [2006] found that dust aerosol deposited above 3000 masl had an Asian geochemical signature and large (4 um) diameter, suggesting rapid trans-Pacific transport, while dust below 3000 masl had a mixed local/exotic source, consistent with dust-related trace element data in the EI record [Gross, 2008]. Therefore, the combined influence of aerosol source, vertical and horizontal transport, and synoptic-scale processes likely play a role in determining the relative importance of East Asian aerosols in the North Pacific across a range of altitudes. These observations are consistent with model results focused on the Arctic that show that for pollutant aerosols, European emissions dominate at the surface, but Asian emissions become progressively more important with altitude and are dominant in the upper troposphere [Shindell et al., 2008; Jacob et al., 2009]. The transport from East Asia at higher altitudes is often a function of warm conveyor belts (WCBs) associated with storm tracks on the east coast of continents [Koch and Hansen, 2005; Stohl, 2006]. We infer, based on our results and those of Pacific airborne sampling campaigns [Jacob et al., 2003; Singh et al., 2009], that a similar vertical gradient between a mixture of North American/Eurasian and East Asian sources at lower altitude to solely East Asian sources at higher altitudes also exists in the North Pacific region.

\section{Summary and Conclusions}

[19] The data presented here represent the first ice core time series of stable $\mathrm{Pb}$ isotopes from the North Pacific and provide direct geochemical evidence of trans-Pacific transport of $\mathrm{Pb}$ pollutants to the St. Elias Mountains. Several 
important conclusions can be drawn from the combination of the $\mathrm{Pb}$ isotopes ratios and concentrations from EI. First, $\mathrm{EF}_{\mathrm{Pb}}$ and ${ }^{208} \mathrm{~Pb} /{ }^{207} \mathrm{~Pb}$ and ${ }^{206} \mathrm{~Pb} /{ }^{207} \mathrm{~Pb}$ ratios suggest that the deposition of anthropogenic $\mathrm{Pb}$ is roughly equal to that of crustal and volcanic sources. Second, the $\mathrm{Pb}$ concentration time series from EI is significantly different from other Northern Hemisphere ice core $\mathrm{Pb}$ records in the latter part of the 20th century and suggests multiple sources of anthropogenic $\mathrm{Pb}$. Time series of $\mathrm{Pb}$ isotope ratios and concentrations in conjunction with meteorological data are used to identify the most important contributing $\mathrm{Pb}$ source regions as East Asia (China and/or Japan) and North America (U.S.). Third, $\mathrm{Pb}$ isotopes from EI shed new light on depositional variability as a function of elevation in the St. Elias Mountains. $\mathrm{Pb}$ isotope ratios from $\mathrm{EI}$ indicate significant deposition of Chinese $\mathrm{Pb}$ at $\sim 3000 \mathrm{~m}$, as was found at the nearby, higher ( $\sim 5000 \mathrm{~m})$ PR Col site [Osterberg et al., 2008]. We contend that there is a vertical source gradient between EI and PR Col defined by a lack of North American aerosols at PR Col (and a much more significant Asian influence), rather than a lack of East Asian aerosols at EI. Additionally, the presence of East Asian $\mathrm{Pb}$ at EI makes it likely that a component of dust deposited at EI is also of East Asian provenance. Fourth, $\mathrm{Pb}$ deposited at EI is isotopically distinct from $\mathrm{Pb}$ at Barrow, Alaska [Sturges et al., 1993], Devon Island [Shotyk et al., 2005], Greenland [Rosman et al., 1993; Sherrell et al., 2000], Mt. Blanc [Rosman et al., 2000] and Mt. Everest [Lee et al., 2011]. This observation, combined with the lack of clear seasonality in $\mathrm{Pb} \mathrm{EF}$ and $\mathrm{Pb}$ isotope ratios and the relatively radiogenic $\mathrm{EI} \mathrm{Pb}$ isotope data argue against a significant input of Western Europe pollution at EI. Fifth, the contribution of East Asian $\mathrm{Pb}$ to EI increased from the 1970 s to the 1990 s, consistent with rising $\mathrm{Pb}$ emissions from East Asian noted in the Mt. Logan summit record. The isotopic composition of $\mathrm{Pb}$ at EI is consistent with coal combustion being the preeminent source of atmospheric $\mathrm{Pb}$ to the North Pacific from $1970-$ 2001 [Chen et al., 2005], despite the fact that leaded gasoline was only banned in China in 1997. The difference in $\mathrm{Pb}$ time series from EI and PR Col exists despite the proximity of the two sites, and the apparent lack of significant contribution of North American Pb to PR Col illustrates that elevation-dependent variability exists and must be accounted for when attempting to interpret regional/global climate signals in records from regions of high relief.

[20] Acknowledgments. We thank D. Introne for stable water isotope analysis and S. Whitlow for major ion analysis of the EI ice core, D. Pasteris, R. Banta, and R. Edwards for assistance in the DRI Ultra-Trace Chemistry Laboratory, E. Blake, A. Mondrick, S. Bastien, M. Waskiewicz, D. Fisher, C. Zdanowicz, A. Williams, S. Williams, A. Wanamaker, and Z. von Hasseln for field assistance, and P. Koons, D. Lux, D. Fisher, C. Zdanowicz, B. Koffman, M. Schwikowski, and two anonymous reviewers for constructive comments. This work was financially supported by NSF awards OPP-0136005 to KJK and OPP-0136146 to CPW, a Climate Change Institute research assistantship and Dan and Betty Churchill Exploration Fund award to B.H.G., and NSF award OPP-0909541, NASA award NAG04GI66G, and support from the Maki Chair of Hydrological Sciences to J.R.M. Data used in this paper are available through the World Data Center for Paleoclimatology Ice Core Gateway website (http://www. ncdc.noaa.gov/paleo/icgate.html).

\section{References}

Alley, R. B., R. C. Finkel, K. Nishiizumi, S. Anandakrishnan, C. A. Shuman, G. Mershon, G. A. Zielinski, and P. A. Mayewski (1995), Changes in continental and sea-salt atmospheric loadings in central Greenland during the most recent deglaciation: Model-based estimates, J. Glaciol., $41,503-514$.

Bahreini, R., J. Jimenez, J. Wang, R. Flagan, J. Seinfeld, J. Jayne, and D. Worsnop (2003), Aircraft-based aérosol size and composition measurements during ACE-Asia using an Aerodyne aerosol mass spectrometer, J. Geophys. Res., 108(D23), 8645, doi:10.1029/2002JD003226.

Bellis, D. J., K. Satake, and C. McLeod (2004), A comparison of lead isotope ratios in the bark pockets and annual rings of two beech trees collected in Derbyshire and South Yorkshire, UK, Sci. Total Environ., 321, 105-113, doi:10.1016/j.scitotenv.2003.08.030.

Bollhöfer, A., and K. J. R. Rosman (2001), Isotopic source signatures for atmospheric lead: The Northern Hemisphere, Geochim. Cosmochim. Acta, 65, 1727-1740, doi:10.1016/S0016-7037(00)00630-X.

Boutron, C. F., U. Gorlach, J. Candelone, M. Bolshov, and R. Delmas (1991), Decrease in anthropogenic lead, cadmium and zinc in Greenland snows since the late $1960 \mathrm{~s}$, Nature, 353, 153-156, doi:10.1038/353153a0.

Cahill, C. (2003), Asian aerosol transport to Alaska during ACE-Asia, J. Geophys. Res., 108(D23), 8664, doi:10.1029/2002JD003271.

Chen, J. M., M. Tan, Y. Li, Y. Zhang, W. Lu, Y. Tong, G. Zhang, and Y. Li (2005), A lead isotope record of Shanghai atmospheric lead emissions in total suspended particles during the period of phasing out of leaded gasoline, Atmos. Environ., 39, 1245-1253, doi:10.1016/j.atmosenv.2004.10.041.

Chow, T. J., and J. L. Earl (1972), Lead isotopes in North American coals, Science, 176, 510-511, doi:10.1126/science.176.4034.510.

Cziczo, D. J., et al. (2009), Inadvertent climate modification due to anthropogenic lead, Nat. Geosci., 2, 333-336, doi:10.1038/ngeo499.

Fuelberg, H. E., D. Harrington, and W. Sessions (2010), A meteorological overview of the ARCTAS 2008 mission, Atmos. Chem. Phys. Discuss., $10,817-842$.

Fukuda, K., and S. Tsunogai (1975), Pb-210 in precipitation in Japan and its implication for transport of continental aerosols across ocean, Tellus, 27, 514-521, doi:10.1111/j.2153-3490.1975.tb01705.x.

Gong, S., X. Zhang, T. Zhao, X. Zhang, L. Barrie, I. McKendry, and C. Zhao (2006), A simulated climatology of Asian dust aerosol and its trans-Pacific transport. Part II. Interannual variability and climate connections, J. Clim., 19(1), 104-122, doi:10.1175/JCLI3606.1.

Goto-Azuma, K., R. Koerner, M. Demuth, and O. Watanabe (2006), Seasonal and spatial variations of snow chemistry on Mt. Logan, Yukon, Canada, Ann. Glaciol., 43, 177-186, doi:10.3189/172756406781812096.

Graney, J. R., A. Halliday, G. Keeler, J. Nriagu, J. Robbins, and S. Norton (1995), Isotopic record of lead pollution in lake sediments from the northeastern United States, Geochim. Cosmochim. Acta, 59, 1715-1728, doi:10.1016/0016-7037(95)00077-D.

Gross, B. (2008), Lithogenic, marine, and anthropogenic aerosols in an ice core from the St. Elias Mountains, Yukon, Canada: Lead-aerosol provenance and seasonal variability, MS thesis, $62 \mathrm{pp}$., Univ. of Maine, Orono.

Hamelin, B., J. Ferrand, L. Alleman, E. Nicholas, and A. Veron (1997), Isotopic evidence of pollutant lead transport from North America to the subtropical North Atlantic gyre, Geochim. Cosmochim. Acta, 61, 4423-4428, doi:10.1016/S0016-7037(97)00242-1.

Han, J. S., K. Moon, J. Ahn, Y. Hong, and Y. Kim (2004), Characteristics of ion components and trace elements of fine particles at Gosan, Korea in spring time from 2001 to 2002, Environ. Monit. Assess., 92, 73-93, doi:10.1023/B:EMAS.0000014510.21563.50.

Holdsworth, G. (2008), Interpreting $\mathrm{H}_{2} \mathrm{O}$ isotope variations in high-altitude ice cores using a cyclone model, J. Geophys. Res., 113, D08103, doi:10.1029/2007JD008639.

Holzer, M., T. Hall, and R. Stull (2005), Seasonality and weather-driven variability of transpacific transport, J. Geophys. Res., 110, D23103, doi:10.1029/2005JD006261.

Hong, S. M., J. Candelone, C. Paterson, and C. Boutron (1994), Greenland ice evidence of hemispheric lead pollution two millennia ago by Greek and Roman civilizations, Science, 265, 1841-1843, doi:10.1126/ science.265.5180.1841.

Huang, J., P. Minnis, B. Chen, Z. Huang, Z. Liu, Q. Zhao, Y. Yi, and J. Ayers (2008), Long-range transport and vertical structure of Asian dust from CALIPSO and surface measurements during PACDEX, J. Geophys. Res., 113, D23212, doi:10.1029/2008JD010620.

Jacob, D., J. Crawford, M. Kleb, V. Connors, R. Bendura, J. Raper, G. Sachse, J. Gille, L. Emmons, and C. Heald (2003), Transport and chemical evolution over the Pacific (TRACE-P) aircraft mission: Design, execution and first results, J. Geophys. Res., 108(D20), 9000, doi:10.1029/ 2002JD003276.

Jacob, D. J., J. Crawford, M. Kleb, V. Connors, R. Bendura, J. Raper, G. Sachse, J. Gille, L. Emmons, and C. Heald (2009), The ARCTAS aircraft mission: Design and execution, Atmos. Chem. Phys. Discuss., 9 17,073-17,123, doi:10.5194/acpd-9-17073-2009. 
Jaffe, D., et al. (1999), Transport of Asian air pollution to North America, Geophys. Res. Lett., 26, 711-714, doi:10.1029/1999GL900100.

Jaffe, D., I. McKendfry, T. Anderson, and H. Price (2003), Six "new" episodes of trans-Pacific transport of air pollutants, Atmos. Environ., 37, 391-404, doi:10.1016/S1352-2310(02)00862-2.

Jones, C., A. Halliday, D. Rea, and R. Owen (2000), Eolian inputs of lead to the North Pacific, Geochim. Cosmochim. Acta, 64(8), 1405-1416, doi:10.1016/S0016-7037(99)00439-1.

Kalnay, E., et al. (1996), The NCEP/NCAR 40-year reanalysis project, Bull. Am. Meteorol. Soc., 77, 437-471, doi:10.1175/1520-0477(1996) 077<0437:TNYRP $>2.0$. CO 2 .

Knüsel, S., D. Piguet, M. Schwikowski, and H. Gaggeler (2003), Accuracy of continuous ice-core trace-element analysis by inductively coupled plasma sector field mass spectrometry, Environ. Sci. Technol., 37(10), 2267-2273, doi:10.1021/es026452o.

Kober, B., M. Wessels, A. Bollhofer, and A. Mangini (1999), Pb isotopes in sediments of Lake Constance, central Europe constrain the heavy metal pathways and the pollution history of the catchment, the lake and the regional atmosphere, Geochim. Cosmochim. Acta, 63, 1293-1303, doi:10.1016/S0016-7037(99)00064-2.

Koch, D., and J. Hansen (2005), Distant origins of arctic black carbon: A Goddard Institute for Space Studies ModelE experiment, J. Geophys. Res., 110, D04204, doi:10.1029/2004JD005296.

Komárek, M., V. Ettler, V. Chrastny, and M. Mihaljevic (2008), Lead isotopes in environmental sciences: A review, Environ. Int., 34, 562-577, doi:10.1016/j.envint.2007.10.005.

Krachler, M., J. Zheng, D. Fisher, and W. Shotyk (2004), Direct determination of lead isotopes $\left({ }^{206} \mathrm{~Pb},{ }^{207} \mathrm{~Pb},{ }^{208} \mathrm{~Pb}\right)$ in Arctic ice samples at picogram per gram levels using inductively coupled plasma-sector field MS coupled with a high-efficiency sample introduction system, Anal. Chem., 76, 5510-5517, doi:10.1021/ac0496190.

Kylander, M., J. Klaminder, R. Bindler, and D. Weiss (2010), Natural lead isotope variations in the atmosphere, Earth Planet. Sci. Lett., 290, 44-53, doi:10.1016/j.epsl.2009.11.055.

Lee, K., S. Hur, S. Hou, L. Burn-Nunes, S. Hong, C. Barbante, C. Boutron, and K. Rosman (2011), Isotopic signatures for natural versus anthropogenic $\mathrm{Pb}$ in high-altitude Mt. Everest ice cores during the past 800 years, Sci. Total Environ., 412-413, 194-202, doi:10.1016/j.scitotenv.2011.10.002.

Liang, Q., L. Jaegle, D. Jaffe, P. Weiss-Penzias, A. Heckman, and J. Snow (2004), Long-range transport of Asian pollution to the northeast Pacific: Seasonal variations and transport pathways of carbon monoxide, J. Geophys. Res., 109, D23S07, doi:10.1029/2003JD004402.

Liang, Q., L. Jaeglé, and J. Wallace (2005), Meteorological indices for Asian outflow and transpacific transport on daily to interannual timescales, J. Geophys. Res., 110, D18308, doi:10.1029/2005JD005788.

Mantua, N. J., and S. R. Hare (2002), The Pacific decadal oscillation, J. Oceanogr., 58, 35-44, doi:10.1023/A:1015820616384.

Marx, S. K., B. Kamber, and H. McGowan (2005), Estimates of Australian dust flux into New Zealand: Quantifying the eastern Australian dust plume pathway using trace element calibrated ${ }^{210} \mathrm{~Pb}$ as a monitor, Earth Planet. Sci. Lett., 239, 336-351, doi:10.1016/j.eps1.2005.09.002.

Marx, S. K., B. Kamber, and H. McGowan (2008), Scavenging of atmospheric trace metal pollutants by mineral dusts: Inter-regional transport of Australian trace metal pollution to New Zealand, Atmos. Environ., 42, 2460-2478, doi:10.1016/j.atmosenv.2007.12.014.

McConnell, J. R., and R. Edwards (2008), Coal burning leaves toxic heavy metal legacy in the Arctic, Proc. Natl. Acad. Sci. U. S. A., 105, 12,140-12,144, doi:10.1073/pnas.0803564105.

McConnell, J. R., G. Lamorey, and M. Hutterli (2002a), A 250-year highresolution record of $\mathrm{Pb}$ flux and crustal enrichment in central Greenland, Geophys. Res. Lett., 29(23), 2130, doi:10.1029/2002GL016016.

McConnell, J. R., G. W. Lamorey, S. W. Lambert, and K. C. Taylor (2002b), Continuous ice-core chemical analyses using inductively coupled plasma mass spectrometry, Environ. Sci. Technol., 36(1), 7-11, doi:10.1021/es011088z.

McConnell, J. R., R. Edwards, G. L. Kok, M. G. Flanner, C. S. Zender, E. S. Saltzman, J. R. Banta, D. R. Pasteris, M. M. Carter, and J. D. W. Kahl (2007a), 20th century industrial black carbon emissions altered Arctic climate forcing, Science, 317, 1381-1384, doi:10.1126/science.1144856.

McConnell, J. R., A. J. Aristarain, J. R. Banta, P. R. Edwards, and J. C. Simões (2007b), 20th century doubling in dust archived in an Antarctic Peninsula ice core parallels climate change and desertification in South America, Proc. Natl. Acad. Sci. U. S. A., 104(14), 5743-5748, doi:10.1073/ pnas.0607657104.

McKendry, I. G., J. Hcker, R. Stull, S. Sakiyama, D. Mignacca, and K. Reid (2001), Long-range transport of Asian dust to the Lower Fraser Valley, British Columbia, Canada, J. Geophys. Res., 106, 18,361-18,370, doi:10.1029/ 2000JD900359.
Millot, R., C. Allegre, J. Gaillardet, and S. Roy (2004), Lead isotope systematics of major river sediments: A new estimate of the $\mathrm{Pb}$ isotopic composition of the upper continental crust, Chem. Geol., 203, 75-90, doi:10.1016/j. chemgeo.2003.09.002.

Mori, I., M. Nishikawa, T. Tanimura, and H. Quan (2003), Change in size distribution and chemical composition of kosa (Asian dust) aerosol during long-range transport, Atmos. Environ., 37, 4253-4263, doi:10.1016/ S1352-2310(03)00535-1

Mukai, H., N. Furuta, T. Fujii, Y. Ambe, K. Sakamoto, and Y. Hashimoto (1993), Characterization of sources of lead in the urban air of Asia using ratios of stable lead isotopes, Environ. Sci. Technol., 27, 1347-1356, doi:10.1021/es00044a009.

Murozumi, M., T. Chow, and C. Patterson (1969), Chemical concentrations of pollutant lead aerosols, terrestrial dusts and sea salts in Greenland and Antarctic snow strata, Geochim. Cosmochim. Acta, 33, 1247-1294, doi:10.1016/0016-7037(69)90045-3.

Nriagu, J. O. (1989), A global assessment of natural sources of atmospheric trace metals, Nature, 338, 47-49, doi:10.1038/338047a0.

Oshima, N., et al. (2004), Asian chemical outflow to the Pacific in late spring observed during the PEACE-B aircraft mission, J. Geophys. Res., 109, D23S05, doi:10.1029/2004JD004976.

Osterberg, E. C., M. Handley, S. Sneed, P. Mayewski, and K. Kreutz (2006), Continuous ice core melter system with discrete sampling for major ion, trace element, and stable isotope analyses, Environ. Sci. Technol., 40, 3355-3361, doi:10.1021/es052536w.

Osterberg, E. C., et al. (2008), Ice core record of rising lead pollution in the North Pacific atmosphere, Geophys. Res. Lett., 35, L05810, doi:10.1029/ 2007GL032680.

Pacyna, J., and E. G. Pacyna (2001), An assessment of global and regional emissions of trace metals to the atmosphere from anthropogenic sources worldwide, Environ. Rev., 9, 269-298, doi:10.1139/a01-012.

Quinn, P. K., G. Shaw, E. Andrews, E. Dutton, T. Ruoho-Airola, and S. Gong (2007), Arctic haze: Current knowledge and knowledge gaps, Tellus, Ser. B, 59, 99-114.

Rhodes, R., J. Baker, M. Millet, and N. Bertler (2011), Experimental investigation of the effects of mineral dust on the reproducibility and accuracy of ice core trace element analyses, Chem. Geol., 286, 207-221.

Rosman, K. J. R., W. Chisholm, C. Boutron, J. Candelone, and U. Gorlach (1993), Isotopic evidence for the source of lead in Greenland snows since the late 1960s, Nature, 362, 333-335, doi:10.1038/362333a0.

Rosman, K. J. R., W. Chisholm, S. Hong, J. P. Candelone, and C. Boutron (1997), Lead from Carthaginian and Roman Spanish mines isotopically identified in Greenland ice dated from 600 B.C. to 300 AD, Environ. Sci. Technol., 31, 3413-3416, doi:10.1021/es970038k.

Rosman, K., C. Ly, K. Ven de Velde, and C. Boutron (2000), A two century record of lead isotopes in high altitude Alpine snow and ice, Earth Planet. Sci. Lett., 176, 413-424, doi:10.1016/S0012-821X(00)00013-3.

Schwikowski, M., et al. (2004), Post-17th-century changes of European lead emissions recorded in high-altitude alpine snow and ice, Environ. Sci. Technol., 38, 957-964, doi:10.1021/es034715o.

Settle, D. M., and C. C. Patterson (1991), Eolian Inputs of Lead to the South Pacific via Rain and Dry Deposition From Industrial and Natural Sources, 294 pp., Mineral. Soc. of Am., New York.

Shaw, G. E. (1982), Evidence for a central Eurasian source area of Arctic haze in Alaska, Nature, 299, 815-818, doi:10.1038/299815a0.

Shaw, G. E. (1995), The Arctic haze phenomenon, Bull. Am. Meteorol. Soc., 76(12), 2403-2413, doi:10.1175/1520-0477(1995)076<2403: TAHP $>2.0 . \mathrm{CO} ; 2$.

Sherrell, R. M., E. Boyle, and B. Hamelin (1992), Isotopic equilibration between dissolved and suspended particulate lead in the Atlantic Ocean: Evidence from ${ }^{210} \mathrm{~Pb}$ and stable $\mathrm{Pb}$ isotopes, J. Geophys. Res., 97, 11,257-11,268, doi:10.1029/92JC00759.

Sherrell, R. M., E. Boyle, N. Harris, and K. Falkner (2000), Temporal variability of $\mathrm{Cd}, \mathrm{Pb}$, and $\mathrm{Pb}$ isotope deposition in central Greenland snow, Geochem. Geophys. Geosyst., 1(1), 1002, doi:10.1029/1999GC000007.

Shindell, D. A., et al. (2008), A multi-model assessment of pollution transport to the Arctic, Atmos. Chem. Phys., 8, 5353-5372, doi:10.5194/acp-85353-2008.

Shotyk, W., A. Cheburkin, P. Appleby, A. Fankhauser, and J. Kramers (1996), Two thousand years of atmospheric arsenic, antimony, and lead deposition recorded in an ombrotrophic peat bog profile, Jura Mountains, Switzerland, Earth Planet. Sci. Lett., 145, E1-E7, doi:10.1016/S0012821X(96)00197-5.

Shotyk, W., J. Zheng, M. Krachler, C. Zdanowicz, R. Koerner, and D. Fisher (2005), Predominance of industrial Pb in recent snow (1994 2004) and ice (1842-1996) from Devon Island, Arctic Canada, Geophys. Res. Lett., 32, L21814, doi:10.1029/2005GL023860.

Simonetti, A., C. Gariepy, and J. Carignan (2003), Tracing sources of atmospheric pollution in western Canada using the $\mathrm{Pb}$ isotopic composition 
and heavy metal abundances of epiphytic lichens, Atmos. Environ., 37, 2853-2865, doi:10.1016/S1352-2310(03)00210-3.

Singh, H., W. Brune, J. Crawford, F. Locke, and D. Jacob (2009), Chemistry and transport of pollution over the Gulf of Mexico and the Pacific: Spring 2006 INTEX-B campaign overview and first results, Atmos. Chem. Phys. Discuss., 9, 363-409, doi:10.5194/acpd-9-363-2009.

Stohl, A. (2006), Characteristics of atmospheric transport in to the Arctic troposphere, J. Geophys. Res., 111, D11306, doi:10.1029/2005JD006888.

Sturges, W. T., J. Hopper, L. Barrie, and R. Schnell (1993), Stable lead-isotope ratios in Alaskan Arctic aerosols, Atmos. Environ., 27, 2865-2871, doi:10.1016/0960-1686(93)90317-R.

Teutsch, N., Y. Erel, L. Halica, and A. Banin (2001), Distribution of natural and anthropogenic lead in Mediterranean soils, Geochim. Cosmochim. Acta, 65, 2853-2864, doi:10.1016/S0016-7037(01)00607-X.

Uno, I., K. Eguchi, K. Yumimoto, T. Takemura, A. Shimizu, M. Uematsu, Z. Liu, Z. Wang, Y. Hara, and N. Sugimoto (2009), Asian dust transported one full circuit around the globe, Nat. Geosci., 2, 557-560, doi:10.1038/ngeo583.

Van de Velde, K., C. Boutron, C. Ferrari, T. Bellomi, C. Barbante, S. Rudnev, and M. Bolshov (1998), Seasonal variations in heavy metals in the 1960s Alpine ice: Sources versus meteorological factors, Earth Planet. Sci. Lett., 164, 521-533, doi:10.1016/S0012-821X(98)00243-X.

Wake, C., K. Yalcin, and N. Gundestrup (2002), The climate signal recorded in the oxygen isotope, accumulation, and major ion time-series from the Eclipse Ice Core, Yukon Territory, Ann. Glaciol., 35, 416422, doi:10.3189/172756402781817266.

Wedepohl, H. K. (1995), The composition of the continental crust, Geochim. Cosmochim. Acta, 59, 1217-1232, doi:10.1016/0016-7037(95) 00038-2.

Yalcin, K. (2005), Glaciochemical records from the St. Elias Mountains, Yukon, Canada, PhD dissertation, Univ. of N. H., Durham.

Yalcin, K., and C. P. Wake (2001), Anthropogenic signals recorded in an ice core from Eclipse Icefield, Yukon Territory, Canada, Geophys. Res. Lett., 28, 4487-4490, doi:10.1029/2001GL013037.
Yalcin, K., C. Wake, and M. Germani (2003), A 100-year record of North Pacific volcanism in an ice core from Eclipse Icefield, Yukon Territory, Canada, J. Geophys. Res., 107(D1), 4012, doi:10.1029/2002JD002449.

Yalcin, K., C. Wake, K. Kreutz, and S. Whitlow (2006a), A 1000-year record of forest fire activity from Eclipse Icefield, Yukon, Canada, Holocene, 16(2), 200-209, doi:10.1191/0959683606hl920rp.

Yalcin, K., C. Wake, K. Kreutz, M. Germani, and S. Whitlow (2006b), Ice core evidence for a second volcanic eruption around 1809 in the Northern Hemisphere, Geophys. Res. Lett., 33, L14706, doi:10.1029/ 2006 GL026013.

Yalcin, K., C. Wake, K. Kreutz, M. Germani, and S. Whitlow (2007), Ice core paleovolcanic records from the St. Elias Mountains, Yukon, Canada, J. Geophys. Res., 112, D08102, doi:10.1029/2006JD007497.

Zdanowicz, C., G. Hall, J. Vaive, Y. Amelin, J. Percival, I. Girard, P. Biscaye, and A. Borys (2006), Asian dustfall in the St. Elias Mountains, Yukon, Canada, Geochim. Cosmochim. Acta, 70, 3493-3507, doi:10.1016/j. gca.2006.05.005.

Zhao, T., S. Gong, X. Zhang, J. Blanchet, I. McKendry, and Z. Zhou (2006), A simulated climatology of Asian dust aerosol and its transPacific transport. Part 1. Mean climate and validation, J. Clim., 19(1), 88-103, doi:10.1175/JCLI3605.1.

Zheng, J., D. Fisher, E. Blake, G. Hall, J. Vaive, M. Krachler, C. Zdanowicz, J. Lam, G. Lawson, and W. Shotyk (2006), An ultra-clean firn core from the Devon Island Ice Cap, Nunavut, Canada, retrieved using a titanium drill specially designed for trace element studies, J. Environ. Monit., 8, 406-413, doi:10.1039/b515886a.

Zheng, J., W. Shotyk, M. Krachler, and D. Fisher (2007), A 15,800-year record of atmospheric lead deposition on the Devon Island Ice Cap, Nunavut, Canada: Natural and anthropogenic enrichments, isotopic composition, and predominant sources, Global Biogeochem. Cycles, 21, GB2027, doi:10.1029/2006GB002897. 